\title{
Merging Wildlife and Environmental Monitoring Approaches with Forensic Principles: Application of Unconventional and Non-Invasive Sampling in Eco- Pharmacovigilance
}

\author{
Ngaio L Richards ${ }^{1 *}, 3$, Sarah W Hall 2,3 , Nancy M Harrison ${ }^{2,4}$, Lata Gautam ${ }^{2,3}$, Karen S Scott ${ }^{5}$, Geraldine Dowling ${ }^{6}$, Irene Zorilla ${ }^{7}$ and Iñigo Fajardo $^{8}$ \\ ${ }^{1}$ Working Dogs for Conservation, 52 Eustis Road, Three Forks, Montana, USA 59752 \\ ${ }^{2}$ Department of Life Sciences, Anglia Ruskin University, East Road Cambridge, CB1 1PT, UK \\ ${ }^{3}$ Forensic Science and Chemistry Research Group, Anglia Ruskin University, East Road Cambridge, CB1 1PT, UK \\ ${ }^{4}$ Animal and Environmental Research Group, Anglia Ruskin University, East Road Cambridge, CB1 1PT, UK \\ ${ }^{5}$ Forensic Science, Arcadia University, 450 S. Easton Road, Glenside, Pennsylvania, USA 19038 \\ ${ }^{6}$ The State Laboratory, Backweston Laboratory Complex, Young's Cross, Celbridge, County Kildare, Ireland \\ ${ }^{7}$ Agencia de Medio Ambiente y Agua de Andalucia, Centro de Análisis y Diagnóstico de la Fauna Silvestre. Consejería de Medio Ambiente y Ordenación del Territorio \\ de la Junta de Andalucía, Spain \\ ${ }^{8}$ Dirección General de Gestión del Medio Natural. Consejería de Medio Ambiente y Ordenación del Territorio de la Junta de Andalucía, Spain; and Vulture Conservation \\ Foundation (VCF), Switzerland \\ "Corresponding author: Ngaio L Richards, Working Dogs for Conservation, 52 Eustis Road, Three Forks, Montana, USA 59752, Tel: 406-529-0384; E- \\ mail:ngaio@workingdogsforconservation.org and ngaio.richards56@gmail.com
}

Received date: January 24, 2014; Accepted date: May 05, 2014; Published date: May 08, 2014

Copyright: (C) 2014 Richards NL, et al. This is an open-access article distributed under the terms of the Creative Commons Attribution License, which permits unrestricted use, distribution, and reproduction in any medium, provided the original author and source are credited.

\begin{abstract}
Pharmaceutical residues in the environment have the potential to harm wildlife. A population's fragility or an animal's secretive nature may preclude capture and the use of invasive/destructive sampling techniques that are typically used in a risk assessment. Conventionally favoured matrices gathered opportunistically from carcasses have a finite lifespan, thereby limiting the detection window. This multidisciplinary paper aims to promote the use of non-invasive approaches and optimize use of even the most degraded carcasses. We highlight a selection of promising alternative, unconventional and underutilized sample types that could be applied in environmental monitoring efforts and wildlife forensic investigations. With a focus on non-steroidal anti-inflammatory drugs (NSAIDs), now under increasing scrutiny in the freshwater and terrestrial environment, we first illustrate current sampling practices and gaps in knowledge by summarizing exposure of: 1) aquatic organisms to urban effluent discharged into waterways, and, 2) scavenging species to veterinary residues in livestock and other carrion. We then consider the merits and limitations of a range of alternative environmentally robust sample options that offer a broader detection interval for NSAIDs, with emphasis on hair, wool and feathers. The viability of eyes/ocular material, bone matter, fecal matter, injection sites, ingesta/pellets and scavenging/coprophagous insects are also discussed.
\end{abstract}

Keywords: Noninvasive monitoring; Environmental monitoring; Wildlife forensics; Environmental forensics; NSAID detection in wildlife; Sentinel species; Old World vultures; River otter; American mink; Eyes/ocular material; Bone matter; Fecal matter; Injection sites; Pellets; Scavenging insects; Coprophagous insects

\section{Introduction}

Certain species are routinely (or selectively) screened for exposure to contaminants, often as part of broader environmental monitoring efforts, to detect relevant patterns over time [1-9]. Basu et al. [10] have outlined characteristics that define a sentinel species, including high trophic status, restricted home range, widespread distribution and ability to bio-accumulate pollutants. A focus on such species makes it possible to obtain a snapshot of trophic and ecosystem health which may reveal chronic and acute exposure patterns. Such monitoring also provides archived resources that can be utilized to develop new, and improve upon existing, sampling strategies and analytical methods to maximize data gained [8]. Results can in turn be drawn from to detect, and therefore potentially mitigate against, future threats to wildlife and their habitats. While the application of wildlife forensics in this context tends to be viewed as a largely reactive process, conducted after a wildlife mortality event following exposure to an acute toxicant/toxin, the breadth of forensic techniques available (most drawn from the human realm), may further enable preventive measures and broaden enforcement options. Effectively two sides of the same coin, forensic methodologies and principles can be incorporated to strengthen wildlife and environmental monitoring efforts.

Two factors may impact the quality and/or quantity of samples recovered from wildlife for contaminant analysis: the degree of invasiveness inherent in obtaining a given sample type and its 'lifespan'. The use of invasive or destructive forms of contaminant monitoring may be restricted or even forbidden if the focal species is imperilled [11,12]. Sampling from a fragile population or attempting to monitor elusive, secretive species will impose further constraints [13-17]. Numerous ethical considerations regarding study designs/ sampling protocols and potential ramifications to individuals while investigating a given population or species, are discussed elsewhere $[18,19]$. A case study, with recommendations for partnership with 
hunters and native communities in order to collect tissue samples and monitor wildlife, is provided in Brook et al. [20]. Such opportunistic approaches aside, it is our view that, on largely ethical grounds, noninvasive and non-destructive approaches should be favoured whenever possible, regardless of whether the focal species is threatened or ubiquitous. Fortunately the breadth of non-invasive monitoring tools available continues to expand. As we will discuss, their role in generating relevant, comparable and high quality information is progressively being recognized, as is the fact that non-invasive approaches often increase sample sizes, and hence sample power, relative to those obtained by conventional means, and they allow monitoring of species not typically 'accessible' via other methods.

Where sampling entails opportunistic recovery of fresh carcasses, soft tissue samples (e.g., kidney or liver), liquid samples (e.g., blood) or ingesta (e.g., gastrointestinal tract, oesophageal or stomach contents) are preferentially recovered for toxicological analysis [21-23]. When acutely toxic compounds are ingested, recovery of the oesophageal passage or stomach contents is especially important, since death is generally so rapid that residues may not have had time to distribute elsewhere [24]. The presence of toxic compounds in these samples also provides tangible evidence of direct exposure, as when seeds coated with a pesticide (and a repellent) were found in the crops of various birds during field trials designed to test the repelling agent's efficacy [25]. While soft tissues and liquid samples are considered optimal, the window of recovery and detection in these samples is often narrowed by environmental conditions (e.g., by extreme heat and humidity causing decay/desiccation), and by scavenger and insect activity, which may hasten decomposition of both the samples themselves and the residues incorporated therein [21]. Several authors of this paper (and many of our colleagues) have repeatedly experienced the frustration of being called to the scene of a mass wildlife mortality, painstakingly collecting carcasses/samples for submission to a laboratory, but obtaining only inconclusive toxicological results due to the level of deterioration of the sample. When wildlife practitioners nonetheless suspect exposure to a toxicant, or supplemental information comes to light suggesting involvement of a different agent than initially suspected, having the option of recovering additional, equally representative samples for follow-up analyses is invaluable. In fact, this can make the difference in terms of positively identifying cause of death, and potentially securing a conviction or penalty.

This review focuses largely on exposure to, and incorporation of, non-steroidal anti-inflammatory drugs (NSAIDs), which are increasingly sought and/or detected in the aquatic and terrestrial environment, and at their interface [26-35]. However, the principles discussed with respect to NSAIDs also apply to numerous other common therapeutic agents including antimicrobials such as antibiotics. Our aim is to highlight the tools and approaches currently available and to improve the versatility and robustness of wildlife/ environmental monitoring and wildlife forensic investigations. Hence, a review was conducted to identify promising and minimally explored sample types:

In which NSAID (and other applicable) residues are rapidly incorporated and remain stable;

That, in living animals, can be non-invasively and readily recovered;

That are more stable/resistant to environmental degradation, thus increasing the number of truly 'useable' opportunistically recovered carcasses.
Initially, two case studies are provided to highlight conventional and novel monitoring/detection research that has assessed exposure in two upper trophic level, sentinel organisms: river otters and vultures. A discussion regarding alternative/unconventional matrices and sampling strategies as they apply to these and other wildlife species then follows.

\section{Case Study 1: Chronic exposure of river otters to NSAIDs in freshwater systems}

Pharmaceutical compounds and their bioactive metabolites are continually introduced into waterways and aquatic environments as complex mixtures in human waste, via treated and untreated municipal wastewater [36-39]. For example, hospital effluent contributes heavily to the load that sewage treatment facilities routinely discharge into rivers, and often reaches sewage networks without preliminary treatment $[40,41]$. Numerous water treatment systems and facilities are not designed for, and consequently do not effectively filter/remove, many of the unanticipated combinations of pharmaceutical compounds that continually flow through them $[33,37,42-45]$.

In rural environments, pharmaceuticals administered to poultry and livestock may also contaminate groundwater [43] or enter surface water directly [45] and through runoff, following application of treated manure or slurry to land [46,47]. The broader issue of NSAID administration to livestock as this pertains to aquatic ecosystem contamination in rural/agricultural sectors and to wildlife exposure risk is, however, outside the scope of this paper. Whether prescribed or purchased over the counter, NSAIDs (e.g., diclofenac, ibuprofen, ketoprofen, naproxen and salicylic acid) are among the primary agents used to treat a range of animal and/or human musculoskeletal ailments [29,33,48-52]. For over a decade, diclofenac and ibuprofen have been amongst the most frequently detected pharmaceutically active compounds in waterways worldwide $[28,30,33,53-56]$.

The uptake and metabolism of NSAIDs (primarily diclofenac, but also ibuprofen) and potential repercussions (e.g., renal, respiratory and reproductive) have already been described in numerous fish species [33,57-62]. While acute exposure/toxicity appears unlikely in wild populations [62], both chronic and 'total mixture' effects may instead be significant $[30,33,45,53,60]$. There still remains a genuine dearth of available studies regarding exposure of wildlife, especially piscivorous species and other higher level predators, to NSAIDs. As top level piscivorous predators, osprey (Pandion haliaetus), otter (Lutra sp.) and mink are generally considered to be representative barometers of aquatic/semi-aquatic ecosystem health [10, 64-71]. Interestingly, the use of mink and otter as sentinels/bio-indicators or related sample types, as both pertain to factors such as contaminant body burden, have been called into question [72,73]. However, by and large, such species are still considered to offer relevant information on local contamination [63], especially when prior levels have not yet been established (i.e., presence/absence). Other such concerns can largely be remedied by awareness of inherent bias and potential confounding effects during study design [74]. Careful consideration of differences in tolerance and physiological responses across taxa (e.g., fish, birds and mammals; [75] will also ensure that the extent and nature of exposure observed in sentinel species can be inferred for their prey and more vulnerable species.

For almost two decades, Simpson (and colleagues) have opportunistically collected and necropsied the carcasses of river otters 
struck by vehicles in the United Kingdom as part of species-specific and environmental monitoring efforts [70,76,77]. Based on their assessment of renal lesions observed, these authors have suggested that future studies investigating renal disease in otters should consider exposure to nephrotoxic agents, such as NSAIDs [78]. This recommendation was also based on a concurrent exploratory study that investigated the viability of using hair to determine exposure to diclofenac and ibuprofen in river otters [79]. In this study, hair was opportunistically collected from a subset of the dead otters $(n=28)$ recovered for necropsy, and both NSAIDs were qualitatively detected. Diclofenac was present on the external surface of 5 of the otter hair samples, signifying passive exposure. After extraction of the hair, diclofenac was also detected in 15 (54\%) of the samples and ibuprofen in $2(7 \%)$, indicating historic ingestion. These findings, which suggest external/dermal exposure within the aquatic medium, and, ingestive exposure via the food chain and through drinking, warrant follow-up investigation regarding the chronic exposure of otters and other aquatic organisms (e.g., mink Mustela sp.) to NSAIDs and other pharmaceuticals in waterways.

Like many mustelids, otters are notoriously elusive and in some places their protected status prohibits or restricts capture and invasive sampling (e.g., for blood collection [11]). This reinforces the case for adopting innovative, non-invasive sampling and monitoring techniques and strategies. While it is straightforward to collect a given volume of hair from a carcass in-hand (e.g., $50 \mathrm{mg}$; [79]) minimally invasive devices such as hair snares/traps may require a significant investment of time for a relatively low yield of hair [11,17]. By contrast, fecal matter can be recovered completely non-invasively and with comparative ease [18]. Indeed, the fecal matter of otters (though not, to our knowledge, of mink) has previously been analyzed for a variety of environmental toxicants $[68,81,82]$. These samples also contain genetic material which can be used to determine exposure on a finer, i.e., individual, scale in relation to territory and habitat usage $[12,82]$. The viability of fecal matter as a sample and a discussion of the contaminants/toxicants previously analyzed therein are further discussed later on. Additional and complimentary methods, such as the use of specially trained detection dogs to optimize the recovery of fecal samples, are also outlined there.

\section{Case Study 2: Chronic and acute exposure of Old World vultures to NSAIDs and related therapeutic agents in livestock and other carrion}

Well-recognized for their ability to dispose of potentially diseased carcasses without themselves serving as propagating agents, vultures perform a virtually irreplaceable ecosystem service in certain global regions [83], i.e., in Africa and Asia. Interestingly, in a human and wildlife forensic context, the signature markings left by vultures on bones during feeding and the characteristic manner they disarticulate cadaver/carcass limbs are increasingly being scrutinized [84,85]. Such information is also useful when assessing the prior risk posed by a carcass subsequently found to have been contaminated by a toxicant, where 'expected casualties' (e.g., scavengers such as vultures) may, however, be absent.

Ecologically speaking, vultures are broadly grouped as New World (Cathartidae, found in the Americas) or Old World (Accipitridae, in Europe, Asia and Africa). These two groups are not considered to share close genetic ties, instead their similarities are attributed to convergent evolution. Most Old World vulture species (e.g., Gyps and Gypaetus) are currently listed as 'Threatened', some as 'Critically
Endangered' by the IUCN. The recent, almost complete collapse of several globally significant Asian Gyps populations has now been convincingly linked to residue exposure, through livestock carcasses, to the NSAID diclofenac [86-88]. In contrast, in Africa, any current veterinary or human NSAID usage and any potential repercussions of this for vulture populations is likely masked, by deliberate and secondary poisoning via pesticides and others $[89,90]$. Here, we consider the status of Old World vulture populations in Asia and Europe, where NSAID usage is known or suspected (respectively) to have had adverse effects on populations. We also briefly discuss the circumstances that led to observed vulture declines, as they pertain to the prediction and identification of future threats, ongoing monitoring and conservation efforts in both locations.

\section{The situation on the Asian subcontinent}

The role of the NSAID diclofenac in reducing populations of three Gyps vulture species on the Indian subcontinent from many tens of millions to $<1-2 \%$ of their original levels - the 'Asian vulture crisis', has been extensively documented and discussed elsewhere [91]. In summary, vultures were widely exposed to residues of diclofenac when they fed on livestock carcasses disposed of in carcass dumps; a common historical practice that artificially inflated Gyps populations, especially in parts of Asia dominated by Hinduism, which considers the cow as sacred and does not permit beef consumption. Vulture consumption of contaminated tissues triggered the onset of fatal visceral gout and, as vulture populations rapidly collapsed, the ecological balance quickly shifted. Far less effective, vector-carrying scavengers (e.g., feral dogs, rats) moved in to take their place. The situation has been deemed so dire for vultures in Asia that small groups of wild individuals have now been captured and housed at special breeding facilities. These individuals will now act as the 'last resort' genetic pool, should wild populations become essentially extinct, and will hopefully be used to re-populate affected regions and 'vulture safe zones', if/when the risk of diclofenac (and other toxic NSAID) exposure is eliminated, a long-term challenge. For further details, see http://www.save-vultures.org/.

Diclofenac was considered the therapeutic agent of choice for livestock owners until the onset of the vulture crisis (discovered in 2004), because of its rapid effects, low cost and widespread availability. However, once conclusively implicated in the extensive vulture mortality, measures were taken (in 2006) to withdraw it from use within the veterinary sector and to identify an effective replacement that would not harm vultures. Rigorous safety trials identified meloxicam as a suitable alternative $[92,93]$ and a campaign was then mounted to work with government authorities and pharmaceutical manufacturers. Banned (in India, Nepal and Pakistan) for veterinary use since 2006, the perception of diclofenac's efficacy nonetheless persists. A 2011 survey regarding the effectiveness of the ban across India highlighted that the drug could still be obtained - for human use - from many pharmacies and was being illegally used on animals $[94,95]$. Be that as it may, veterinary use of diclofenac appears to have halved since 2006, and surveys conducted across India and Nepal indicate that vulture populations seem to be stabilizing $[88,94,95]$. Further measures to remove human formulations of diclofenac from the market, or restrict their availability, are ongoing and clearly essential going forward.

The collection and analysis of tissues from carcasses available to vultures across Asia - to determine compliance with the diclofenac ban and assess the persisting exposure risk from diclofenac and other 
NSAIDs - is an integral ongoing activity [96-99]. In a series of widespread surveys undertaken since 2005 across India $[94,96,97,99]$ detectable residues of diclofenac in cow/buffalo carcass liver tissues have been found in 1 in 10 (decreasing to 1 in 20 more recently) samples tested. In a controlled study to examine the half-life and body clearance rate of a 'normal' veterinary dose (i.e., $1000 \mathrm{mg} / \mathrm{kg}$ by body weight) of diclofenac in Indian cow and goat (Bos indicus and Capra hircus) [96], residues of the drug were not detected in tissues (i.e., kidney, liver and intestine) after 7 days and 26 hours, respectively, post-administration of a single intramuscular injection. Consequently, livestock animals purchased for vulture restaurants and captive facilities are now commonly held for at least one week prior to slaughter to ensure that complete elimination of any existing tissue diclofenac residues occurs [100]. The International SAVE (Saving Asia's Vultures from Extinction) research and conservation consortium now hopes that several regions in Asia will be entirely free of diclofenac soon (at the time of writing), and that vulture release from captive stock could therefore commence by 2016 (http:// www.rspb.org.uk/supporting/campaigns/impact/vulture/nearlysaved.aspx).

\section{The situation in the European union}

In contrast to the previously described scenario regarding Gyps populations on the Asian subcontinent, the situation within the European Union (EU) is far more nuanced. Here - at least at the time of writing - certain species appeared robust whereas others, such as the bearded vulture (Gyps barbaetus) and Egyptian vulture (Neophron percnopterus), are currently under threat $[101,102]$. It is noteworthy that, whilst this review was being finalized, the precarious situation of the Egyptian vulture was emerging, with possible remedial action plans under discussion. Furthermore - again around the time of finalizing the review - diclofenac was 'newly' registered for veterinary use in some European countries (e.g., Spain and Italy). Regardless, even if the presence and availability of veterinary agents including NSAIDs in livestock carcasses were incidental in the EU, any repercussions arising from exposure could place an additional, unsustainable strain on such faltering populations.

A longstanding history of deliberate (and illegal) poisoning of predators in hunting and farming districts lies at the heart of the majority of vulture population declines across their European ranges [103]. However, changes to both food resource availability and quality are also relevant factors [104,105]. In 2000, a severe outbreak of BSE (bovine spongiform encephalitis, or 'mad cow disease') forced the EU to enact carcass control measures (regulation 1774/2002; [106,107] in essence stipulating that fallen stock must be immediately (and 'safely') disposed of. In Spain, which is a European stronghold for vultures, the measures were not strictly adhered to in many rural areas partly due to the remoteness and distances of these areas [106]. Livestock carcasses are also managed by local Spanish authorities, in 'muladares' or traditional carcass dumps/feeding stations, and there is concern that these may be causing vultures to modify their feeding and foraging behavior by serving as a focal feeding point [108].

The dual concern is that these sites likely predispose vultures to a diet of intensively reared - and hence - heavily medicated stock, as was the case on the Indian subcontinent, but the absolute safety of these carcasses to vultures has not yet been satisfactorily confirmed, either in Spain or other parts of Europe. Several studies [109-111], now all retracted from publication, have suggested the occurrence of widespread exposure of vultures to NSAIDs (e.g., flunixin and aspirin) antimicrobials (e.g., enrofloxacin) at carcass dumps/feeding stations in Spain.

The fact that these studies were all retracted after scrutiny is unfortunate, but it does not invalidate this line of inquiry. In many parts of western Europe (e.g., Spain, Portugal and France), a permit can be obtained to provide cattle, goat, sheep, pig and horse carcasses to both wild and captive vultures, at breeding and rehabilitation facilities. Yet within the EU there is a concerning absence of clarity regarding the prevalence of veterinary agents (NSAIDs and others) in the animal carcasses provided for scavengers. Likewise, the potential risks posed to vultures and other scavenging species, including ecologically important insect assemblages remains virtually unstudied. Generally speaking, far more information is urgently needed regarding NSAIDs known or suspected to cause gout-related mortality (e.g. carprofen, ibuprofen, ketoprofen, flunixin, phenylbutazone) [112-114], no less so now that diclofenac has been registered for veterinary use in some parts of Europe, especially Spain. This will entail assessing the disposition of these agents in a relevant suite of agricultural animals, conducting safety trials with vultures (or a vulture cell line) and actively monitoring for residue levels in livestock carcasses.

Two simultaneously important monitoring goals/actions will be to:

identify the agents/compounds of concern and create a targeted screening list;

routinely screen intact livestock carcasses and partial components (i.e., bait material) for presence/absence of veterinary agent residues which may pose a risk to scavengers (whether or not other, more 'prominent' compounds are detected).

These efforts would be facilitated by the availability of a suitable suite of analytical approaches and through the greater utilization of novel, unconventional samples in which presence/absence of agents of concern can be assessed. This would also strengthen datasets by increasing sample size through the capacity to recover residues from carcasses that would previously have been considered too degraded. By carrying out such work, improved risk assessment tailored to multiple scavenging species could be achieved, as discussed in Richards et al. [80]. Relevant, environmentally robust samples, in which residues may be 'locked in' once an individual is exposed to an agent (e.g., hair and ocular material) are further discussed later on.

\section{Sample Matrices for further Consideration in Wildlife Monitoring and Wildlife Forensic Investigations}

The previous section discussed two wildlife monitoring case studies, and considered the use of primarily conventional strategies and more novel approaches. In turn, we outlined certain priorities for further research in these cases. In this section, several promising, environmentally robust sample types are highlighted for further consideration in wildlife monitoring and forensic efforts. This includes a discussion of both the advantages and limitations of each proposed sample matrix. The primary focus is on the incorporation of NSAIDs into animal hair (or pelage), wool and feathers, which also have the advantage that they can, in most cases, be collected non-invasively. Fecal matter (often referred to as 'scat' in wildlife monitoring circles), is also discussed as a non-invasive and, in some realms, unconventional sample. This is followed by a brief discussion of other matrices that have come to our attention in this context: ocular material, bone matter, injection site tissues, cast pellets/ingesta/ 
vomitus/gastric contents and scavenging insects. Several of the aforementioned matrices may also be ingested by scavenging species which include ecologically important insect assemblages, and as such may represent an exposure hazard. This possibility is also explored and discussed as it could be incorporated into a risk assessment when appropriate.

\section{Principles of growth, exposure and incorporation into human hair as this applies to animal species}

Initiated in the 1960s and 1970s to assess human exposure to heavy metals [115], the analysis of hair has since gained increasing acceptance as a viable alternative to that of blood and urine for drug testing in forensic toxicology [115-117]. It has also been analyzed in conjunction with pesticide intoxication cases [118,119]. The fundamentals of hair analysis have been summarized elsewhere [e.g., 120]. Here, we briefly reiterate the key principles of growth and incorporation as they directly relate to detecting contaminant/ pharmaceutical exposure in wildlife.

First, hair is only actively growing while the lower follicle is developing and a hair shaft is being produced (i.e., the anagen phase) [121]. During this phase, the hair follicle is bathed and nourished by the bloodstream and compound residues circulating therein can be incorporated into the hair [122] and effectively locked into its keratinized structure and along its length as it grows out [123]. The predominant factors that influence a compound's incorporation into hair (e.g., affinity for binding to melanin, quantity and type of melanin present and lipophilicity) are discussed elsewhere [119,124-126]. However, whilst the basic principles of incorporation apply to both human and animal hair, some important differences exist. For example, the color of animal hair varies among species and individuals [134], to a much greater degree even than is the case with human hair [125]. Since this factor can affect the uniformity and distribution of incorporated residues, it should be fully factored into any quantitative or even qualitative analyses conducted.

Once formed, hair is highly resistant to environmental degradation [117]. For this reason, compounds that incorporate into hair can be detected in this sample well after they would cease to be detected in tissue, plasma and urine $[115,123,127,128]$. This is shown in Table 1, which summarizes (in increasing order), the timeframe of detection for drugs of abuse in selected human sample matrices.

\begin{tabular}{|l|l|}
\hline Matrix & $\begin{array}{l}\text { Detection timeframe in hours or } \\
\text { days }^{\mathrm{a}, \mathrm{b}}\end{array}$ \\
\hline Saliva & $1-36 \mathrm{hrs}$ \\
\hline Blood / plasma & $1-2$ \\
\hline Urine & $1-7$ \\
\hline Sweat & $1-14$ \\
\hline Hair (cut) & $7->100$ \\
\hline Hair (plucked) & $1->100$ \\
\hline $\begin{array}{l}\text { aBoumba et al. [116] } \\
\text { bDolan et al. [230] }\end{array}$ \\
\hline
\end{tabular}

Table 1: Typical timeframe of detection for drugs of abuse and their metabolites in human biological samples.
As previously discussed, wildlife species may be exposed to acute and/or chronic levels of NSAIDs (or other agents) in the environment - either passively or via consumption of dosed or exposed prey/ carrion. In theory, residues could be incorporated into hair as early as several hours after exposure [129]. However, that portion of the hair may not reach the surface of the skin for days or weeks $[130,131]$. Plucking even a minimal sample of hair (e.g., equivalent to $10 \mathrm{mg}$ ) right to the roots is only really feasible in the deceased because of the level of discomfort involved and the strain this can place on the hair itself. In summary, while hair may often be an unsuitable, impractical or sub-optimal sample for identification of acute exposure to a toxicant particularly if other conventional samples are available - it is a particularly useful matrix for evaluating chronic exposure to therapeutic levels of compounds (e.g., a veterinary profile) $[132,133]$.

\section{Applications of animal pelage}

Three principal types of hair are found on domestic animals: 1) guard, 2) fleece and 3) tactile hairs or vibrissae [134]. Guard hairs (e.g., mane and tail hair of horses, bristles of pigs) form the smooth outer coat. Sheep's wool, or fleece, lacks guard hairs and instead is made up of long, fine hairs that are also soft and curly [135]. Tactile hairs, which are thicker and usually longer than guard hairs, are most commonly found on the face, around the lips and the eyes [135], and have only been sampled on occasion [136]. Used as probes or 'feelers', these long, stiff hairs with specialised innervations are sometimes called 'sinus hairs' because a large, blood-filled sinus surrounds the deeper portions of the follicle [135]. This connection to the bloodstream suggests that residues would be incorporated into tactile hairs, making them potentially suitable for residue analysis. However, from an animal welfare perspective, these samples should only be collected from carcasses.

It is also important to consider the rate at which hair grows. This can vary among different animal breeds and on different parts of the body $[137,138]$. In domestic animals, the duration of the anagen phase is genetically determined for each hair type in a given species [139]. There is also evidence that hair growth varies with season $[139,140]$. Most adult fur-bearing animals have two seasoned molts per year [135], where the light coat worn in the summer is replaced by a heavier winter coat [134]. Cattle usually shed their coats twice a year and individual follicles produce two or three hairs per year with a resting stage between each [135]. Hair follicle activity, which influences growth rate, is highest in summer and lowest in winter which suggests that maximal sensitivity for drug detection should be in summer, when incorporation would be most effective. Popot et al. (2001) [140] recommend sampling hair from the neck and back of horses in the autumn whilst pre-winter growth occurs to detect drugs administered one month previously. It must also be noted, however, that hair is replaced more frequently in animals that are housed outside [131].

Regardless of type or growth rate, animal hair can also be sampled when an agent is known to have been administered topically. For example, the organophosphorus insecticide, famphur, topically applied to livestock to treat against ecto- and endo-parasites, persisted on the hair of cattle for up to 100 days after treatment, and magpies (Pica pica) were then poisoned when they ingested it [141]. Similar incidents have been reported for eagles and other birds of prey that have scavenged on livestock topically treated with other organophosphorus insecticides [142]. Numerous NSAIDs and veterinary agents are administered as a topical gel, though to our knowledge the possibility that scavenging wildlife could be exposed via 
this route has not yet been explored. Species that come into contact with pelage orally, either when collecting it for nesting purposes, or when feeding on a carcass, may be exposed to residues of topically applied agents. Similarly, our opportunistic analysis of otter hair showed the viability of analyzing surface hair washes to identify dermal exposure and refine the information obtained regarding ongoing exposure to compounds of interest within a given environment [79].

\section{Sheep's wool: atypical growth, incorporation and exposure determination}

Wool is considered an atypical sample matrix because it remains in continuous anagen phase, in contrast to other types of animal pelage [135]. External washes of sheep's wool are routinely screened for residues of veterinary agents as part of quality control, consumer protection measures and the assessment of possible environmental contamination $[143,144]$. Residues of potentially harmful compounds may therefore be detected in wool long after they have been cleared from the body. Sheep are administered a range of anti-nociceptive compounds (e.g., the NSAID flunixin), antibiotics, anthelmintics and endectocides (e.g., avermectins such as ivermectin), among others. For practical reasons, sheep reared extensively (that is to say allowed to roam and graze freely in generally remote locations), may be administered control-release capsules (e.g., of ivermectin), which emit a given amount on a daily basis [145]. Knowing when sheep were last sheared (i.e., the first point at which new wool could begin incorporating subsequent residues), would enable more accurate estimation of whether and when a compound of interest was administered.

Untreated wool has an oily feel due to the presence of lanolin. Also known as wool 'grease' or wool 'wax', lanolin is a product of cutaneous sebaceous glands [134]. Residues may be extruded onto the wool's surface in lanolin, where they are likely to remain unless washed off. As such, oral contact with/consumption of wool may pose a risk to species that use wool to line their nests. For this reason, a qualitative analysis of wool was conducted by [80] and the NSAID flunixin was detected on the exterior of the wool (through 'washing') and in extracts of the wool itself. These results have also led to follow-up work utilising quantitative analysis targeting NSAIDs and other compounds of conservation concern (e.g., antimicrobials) of sheep's wool recovered from bearded vulture nests in Spain (Greeves et al., unpublished data).

\section{Feathers: growth, exposure and incorporation, with an emphasis on vultures and condors}

The analysis of feathers during forensic investigations has primarily consisted of physical examination in suspected cases of illegal trafficking, possession of protected species/feathers, and following wildlife mortality/debilitation events (http://www.fws.gov/lab/featheratlas/ index.php). This section focuses on how feather analysis offers relevant information regarding the presence of contaminants in both the terrestrial and aquatic environment. Like human hair, feather analysis techniques were pioneered in the 1960s to investigate avian exposure to heavy metals [146]. There is evidence that birds reduce their body burden of heavy metals by offloading or excreting metals into their growing feathers, particularly the primary and secondary feathers [147,148]. A number of heavy metals have been detected in the feathers of living and deceased raptor, seabird/shorebird and passerine species $[147,149-156]$. Exposure to heavy metals can be direct, namely through ingestion of contaminated material [147], or passive - via atmospheric deposition onto the feathers [154]. For example, elevated concentrations of lead have been detected in the feathers of vultures and condors [157] and it was surmised that an observed interruption in flight feather shedding (by turkey vultures (Cathartes aura)) over a one year period may have been due to lead poisoning [158].

Feathers are inert epidermal structures, composed primarily of keratin with formations resembling human hair. Arranged in a complex pattern of tracts over the body of the bird [159], each feather is unique in color, shape, size and pattern [157]. Like hair, the feather cycle has a growth (or anagen) phase, which spans several days or months, and the resting (or telogen) phase may span a few days to approximately 14 months, depending upon the species and, potentially, the feather type [160]. Feathers grow out of follicles derived from the epithelial and dermal layers of the skin. At the base of the feather follicle is the pulp, which is rich in blood vessels. A central axial artery and numerous vessels and capillaries surround the developing feather. As such, mature feathers are richly connected with muscles, nerves and blood vessels in the dermis [160]. Residues of ingested compounds are incorporated in much the same manner as they are into hair: i.e., from the lower portion of the feather (the calamus) during the growth phase, while the feather is connected to the bloodstream through small blood vessels [146,161]. After the feather is fully formed these vessels atrophy and residues cease to be incorporated (the catagen phase) [162]. The feather then remains attached to the follicle as an inert appendage, until it is shed.

There are five major types of feather: 1) contour/veined; 2) down/ body; 3) powder; 4) semiplumes; and 5) bristles. Contour or veined feathers include the major flight feathers of the wing and of the tail as well as those on the trunk [163]. Down feathers are radially symmetric, fluffy, and mostly present on the ventral trunk to insulate the body [163]. Powder feathers, which grow continuously and are never molted [159], also provide insulation. Semiplumes are found beneath contour feathers, and, like down feathers, are fluffy, lack interlocking barbules and barbicels and may contribute to insulation [164]. Bristles, which are stiff whisker-like projections, perform a number of functions, including funnelling insects into the mouth [159]. In this regard they can be compared to tactile hairs. The colors displayed in avian plumage are due to structural adaptations in the feathers and to the presence of a variety of pigments, including melanins [162]. This is an important consideration when evaluating which feathers to analyze quantitatively because compounds of interest may bind in different amounts based on the concentration and type of these pigments. For a detailed discussion of the principal pigments found in bird feathers see Proctor and Lynch [159].

The rhythm of molt and rate of feather growth are species specific traits, rapid for some and protracted for others. They can also vary depending on whether a species or population is migratory or sedentary [165]. The viability of feather analysis in determining presence/absence of a given compound or substance in any particular species must be assessed relative to these factors. When feathers are rapidly replaced, there is a narrower timeframe during which growth and exposure to a given compound may overlap. If this is the case, analysis of feathers might not reveal that any (recent) exposure has in fact taken place. However for other species, molt can be a more drawn out process, with feather growth continuing over much of the year. This is the pattern typical of larger and longer-lived species such as seabirds and birds of prey, which are often (but not always) those most vulnerable to environmental contaminations. For example, the growth 
Citation: Richards NL, Hall SW, Harrison NM, Gautam L, Scott KS, et al. (2014) Merging Wildlife and Environmental Monitoring Approaches with Forensic Principles: Application of Unconventional and Non-Invasive Sampling in Eco-Pharmacovigilance. J Forensic Res 5: 228. doi: $10.4172 / 2157-7145.1000228$

Page 7 of 16

of a single California condor (Gymnogyps californianus) feather may take up to 4 months [157]. Snyder and colleagues (1987) [231] found that the primary feathers of the California condor grew for a period of between 105 and 120 days, corresponding to a growth rate of 4.5 to 6.0 $\mathrm{mm} /$ day. Houston (1975) [166] observed a vulture feather growth rate of $4.7 \mathrm{~mm} /$ day in, which is much greater than the $0.23 \mathrm{~mm} /$ day estimated for calf hair (Table 2).

It is not known whether a more elevated rate of growth is accompanied by a correspondingly lower level of contaminant incorporation; however, work conducted by Furness and colleagues [152] suggests that this may indeed be the case. And for example, we note that residue levels of methamphetamine $(\mathrm{ng} / \mathrm{mg})$ detected in (comparatively slow-growing) human pubic hair were more than double those in head hair [167].
Given the lengthy duration of their growth phase, both primary and secondary feathers should be ideal samples to analyze for residues of a number of compounds in vultures. However, obtaining a permit to remove feathers from an imperilled species may not be allowed. In any case, removing primary or secondary feathers in living birds is unacceptable from an animal welfare perspective. By contrast, use of body feathers is relatively non-invasive, does not disrupt flight, and allows for collection from several locations on the body $[157,159,162]$. Powder feathers, which grow continuously and are never molted [159], should also be investigated as potentially suitable for detecting compounds of concern. Table 2 compares the growth rate of selected vulture feathers, human and animal hair (and human nails, for comparison).

\begin{tabular}{|c|c|c|}
\hline Sample & Species & Monthly growth rate in $\mathrm{mm} /$ day \\
\hline Primary feather & California condor & $4.5-6^{\mathrm{a}}$ \\
\hline Primary feather & Oriental white-backed vulture & $4.7^{\mathrm{b}}$ \\
\hline Hair (mane) & Horse & $\begin{array}{l}0.59^{\mathrm{c}} \\
0.77-0.8^{\mathrm{d}}\end{array}$ \\
\hline & & $0.72^{\mathrm{e}}$ \\
\hline Hair (flank) & Calf & $0.21-0.25^{f}$ \\
\hline Hair (shoulder) & Domestic dog & $0.49-0.96^{g}$ \\
\hline Hair & Human & $0.36^{\mathrm{h}, \mathrm{i}}$ \\
\hline Nail & Human & $0.10^{\mathrm{j}}$ \\
\hline \multicolumn{3}{|c|}{ aSnyder et al. [231] } \\
\hline \multicolumn{3}{|l|}{ bHouston [166] } \\
\hline \multicolumn{3}{|c|}{ cWhittem et al. [232] } \\
\hline \multicolumn{3}{|c|}{ dPopot et al. [140] } \\
\hline \multicolumn{3}{|c|}{ eTracey et al. [233] } \\
\hline \multicolumn{3}{|c|}{ fGaillard et al. [131] } \\
\hline \multicolumn{3}{|c|}{ 9Gunaratram and Wilkinson [137] } \\
\hline \multicolumn{3}{|c|}{ n'Sachs and Raff [234] } \\
\hline \multicolumn{3}{|l|}{ iWennig [235] } \\
\hline jLin et al. [128] & & \\
\hline
\end{tabular}

Table 2: Monthly growth of selected keratinous matrices in various species

The use of any veterinary agent to augment body mass, or whose consumption poses a risk to human health (e.g., anabolic steroids, $\beta$ agonists and nitrofuran antibiotics) must be carefully monitored $[168,169]$. Poultry feathers are routinely monitored as part of human food safety testing procedures. Recently, residues of antimicrobials, pharmaceuticals and arsenic were detected in (poultry) feather meal, often sold as fertilizer and animal feed [170,171]. Relative to other sampled tissues (e.g., plasma, fat, muscle and kidney), $\beta$-agonist growth promoters such as clenbuterol and salbutamol were detected in significantly higher concentrations in chicken feathers. They were also detectable 43 days after withdrawal, leading the authors to recommend the use of this matrix for detection of illegal administration [169]. Theoretically, the presence of an acutely toxic compound can be detected in the feathers of wildlife species. The recovered feather(s) must have been in the growth phase at the time of exposure, and a sufficient interval must have passed between exposure and death for residues to reach the bloodstream then be incorporated in the highly vascularised pulp. For example, the growth period of primary and secondary feathers of vultures is on the order of months, which greatly exceeds the period during which toxic effects are normally manifested to diclofenac (e.g., 36 - 58 hours between exposure of Gyps vultures to diclofenac and death; [87]). That being the case, residues would potentially be integrated at the root end of a growing feather. As this remains unproven, it therefore remains necessary to establish the timeframe between exposure and incorporation into feathers on a compound-by-compound basis. Another difficulty lies in being able to 
identify the feathers where growth coincided with exposure in order to harvest them for analysis. In some cases, feathers in growth phase can be visibly distinguished [166], which means they could be preferentially selected from carcasses for analysis and assessment of recent exposure. Discarded vulture feathers have also been noted around carcass remains $[84,166]$.

\section{Analysis of fecal matter}

In a forensic/regulatory context, the fecal matter of food and racing animals has been analyzed for a number of potentially harmful/illicitly used compounds [172-175], including NSAIDs [176]. Residues of veterinary drugs and pharmaceutical agents are increasingly being sought in fecal matter as part of environmental and wildlife monitoring efforts. In the aquatic environment, inputs of fecal matter (e.g., as effluent from cattle feedlots) have been associated with endocrine disruption and reproductive repercussions to fish species [47]. From a terrestrial monitoring perspective, widespread use of manuring (from human and animal biosolids) in agricultural systems may be contributing to the spread of antibiotic resistance in wildlife [177], and to an increase in heavy metal soil burdens in, and bioavailability to, micro-organisms and plants [178] among others.

To our knowledge, neither the dung of often highly medicated livestock nor the fecal matter of vultures - often observed by carcasses and remains $[84,166]$ - has been collected or analyzed for residues of NSAIDs. However, ecologically important insect assemblages and other already vulnerable species may be exposed to such residues, with as yet unknown consequences (e.g., the Egyptian vulture, which is coprophagous [179-180] and rapidly declining in some parts of its range [181,182]. Residues of antiparasitic agents (e.g., endectocides like ivermectin) in the dung of livestock animals can be harmful to a number of coprophagous insects [183-186] that perform similar ecosystem services to vultures, but on a less obvious microscale. Consequently, the presence of NSAID residues and other relevant harmful compounds - and their persistence in fecal matter - should be better established. Sampling, preservation and study protocols involving feces must reflect that the fecal matter itself and the incorporated compounds could degrade or be modified over time due to weathering by rain and temperature-induced degradation, among other environmental factors [187].

Faced with such constraints, and the need for expediency, the use of specialized tools such as detection dogs may be invaluable in terms of rapidly recovering high quality samples for analysis. Detection dogs are increasingly being used to non-invasively recover wildlife fecal matter during conservation and monitoring studies - particularly where rare and elusive species are involved $[188,189]$. This technique has steadily gained recognition, especially given its inherent efficiency, resulting in greater sample sizes [16,190]. In parallel, fecal matter has become widely accepted as a viable and data rich sample containing a wealth of genetic, reproductive, dietary and contaminant information $[15,16,18,191,192]$. Though primarily utilized in terrestrial environments, 'scat dogs' or 'conservation detection dogs' have also been deployed to search for fecal matter in aquatic ecosystems, $[193,194]$. Similarly, detection dogs were dispatched to find the fecal matter of river otter and mink along riverways to assess presence/ absence of several classes of compounds, including NSAIDs, therein (Working Dogs for Conservation, unpublished data). With the exception of NSAIDs and other pharmaceuticals/veterinary agents, numerous classes of contaminants have previously been sought and detected in otter fecal matter [12,81,195-198].

\section{Additional unconventional samples for consideration in environmental, wildlife monitoring and wildlife forensic investigations}

This section considers four additional sample matrices and one broad sample category that may be useful in wildlife forensic/ environmental monitoring efforts, and which we believe are worthy of further consideration. In some cases, consumption of these components may pose a secondary exposure risk to vultures and possibly other scavenging species. As such, the analysis of these samples may also provide important information for risk assessments conducted to steer conservation efforts and mitigation measures.

\section{Analysis of ocular material}

Eyes and ocular material are analyzed as part of veterinary and safety monitoring efforts. The iris, ciliary body, choroid and retinal layers of the eye all contain melanin [199], identified as the binding site for drugs in pigmented ocular tissues [200]. The retina has also been described as a metabolic 'dead-end' tissue, where residues of parent compounds and metabolites accumulate at high concentrations and are not subject to the higher cellular turnover and clearance rates of tissues such as the liver [199]. For example, while concentrations of the $ß$-agonist clenbuterol decreased in the muscle and plasma of broiler chickens and were no longer detectable between 24 and 48 hours after withdrawal, eyes (and feathers, as previously discussed) still contained detectable residues 43 days later [169]. Cooper and colleagues (2008) [168] also detected residues of nitrofuran in the eyes (primarily in the retina) of broiler chickens fed a diet consisting of a sub-therapeutic level of the antibiotic, with ocular concentrations of the metabolite that were significantly higher than in muscle or liver. Similarly, Cooper and Kennedy [199] noted that nitrofuran metabolites accumulated in the retina of pigs fed therapeutic doses, at concentrations an order of magnitude higher than those seen in edible tissues (e.g., muscle). They concluded that the elevated retinal concentrations and long depletion half-lives observed for all four of the nitrofuran metabolites indicated these would be detectable at the time of slaughter in the retinas of pigs fed a therapeutic dose at any point in their lifetime [199]. While nitrofurans apparently show lengthy depletion half-lives and very elevated residues in the retinas of food animals, not all B-agonists accumulate to the same extent [199]. Hence, the incorporation and persistence of different compounds must be established in ocular material on a case-by-case basis. Given that elevated retinal concentrations have typically been observed and that retina is a sparse and difficult matrix to work with, the analysis of whole eyeballs has also been recommended [199].

In terms of sampling, the eyes may be partially protected from environmental decay by the eyelids and their recessed encasement within the skull. However, eyes are frequently scavenged, for example by Egyptian vultures [201] and by griffon vultures (Infante, Martinez and Martín, Personal Communication). If, over time, there is delayed clearance of residues and/or bio-concentration, consumption of this matrix may prove harmful, particularly if an individual is exposed to residues via other pathways or sources as well. Analysis of ocular material could also be used to establish the longer-term veterinary profile of livestock animals deposited in carcass dumps and at feeding stations. This could be used to evaluate compliance with regulatory frameworks and identify illegal administration of therapeutic agents, even following a significant withdrawal period or after lengthy exposure to environmental elements. Similarly, the eyes/ocular material of selected aquatic organisms could be analysed to determine 
which suite of pharmaceutical and veterinary agents they have been exposed to within waterways. If the analysis of eyes were shown to be viable, then it would provide an additional sampling matrix to explore exposure. This may require different sample preparation or analytical screening methods (an avenue currently being explored collaboratively by one of the authors of this review).

\section{Analysis of bone, bone marrow and synovial fluid}

Very few studies have investigated the presence of pharmaceutical or veterinary agents in bone $[23,202]$. Yet numerous illicit drugs have been detected as part of toxicological and forensic analysis [203-206]. Due to its lipid content and rich vascular supply, compounds present in the bloodstream should readily diffuse into bone marrow [207], especially lipophilic compounds such as NSAIDs [208]. Marrow is housed inside the bone, and as such, any incorporated residues should have some degree of protection against environmental decomposition and contamination [202]. Noguchi et al. (1978) [207] analysed dried bone marrow from a severely decomposed body. Dried lung, muscle tissue and skeletal matter were the only matrices that remained suitable for analysis. Similarly, Kojima and colleagues (1986) [209] were able to detect methamphetamine and amphetamine in femoral bone marrow from a skeletonised body that had been wrapped and buried in a blanket for five years. As previously discussed, a number of pharmaceutical compounds prescribed to treat inflammation including diclofenac which is highly protein-bound [210] - can also come into contact with bone matter through the blood stream or the synovial fluid. The synovium is a soft membrane that lines the noncartilaginous surfaces within the synovial joints. Synovial fluid fills the cavities within the joints, which reduces friction between the cartilage and cushions the joints during movement. Inflammation in the joints increases the protein concentration in the synovial fluid. One would therefore expect more albumin-bound compounds to be present in the fluid of an inflamed joint than of a healthy joint. In humans, certain compounds (e.g., diclofenac) are known to accumulate at the site of inflammation, where they reach concentrations similar to those observed in plasma [211]. Although the maximum concentration of diclofenac in synovial fluid is lower than in plasma, its half-life is three times greater [212]. As a result, it takes longer for diclofenac to be cleared from the synovial fluid than from plasma, which means it surrounds the bone for a longer period [212]. A detailed discussion of caveats of compound residue incorporation into bones, and their analysis, has been published [23].

Given that a group of vultures can strip a buffalo-sized carcass completely, leaving only the skeleton, in a matter of hours [213], bone may be one of the few samples left to collect for subsequent analysis. In this regard, it is particularly important to determine how quickly compound residues can be incorporated into bone, how long they persist and whether or not they present an exposure threat to species like the bearded vulture, whose diet consists predominately of bones $[102,214]$.

\section{Analysis of injection sites for indications of recent exposure}

During post-mortem investigation, cadavers are systematically examined for the presence of irregularities, and tissues around potential injection sites are routinely sampled for poisons and drug analysis (http://www.tiaft.org/node/86). Drug residues (e.g., heroin) and concentrations found in tissues at injection sites have been used to identify whether rapid versus delayed death occurred and to establish cause of death and foul play $[215,216]$. In addition to oral, topical and rectal routes, NSAIDs may also be administered intramuscularly and intravenously [217] sometimes to reduce gastric irritation [208]. In some instances a withdrawal period has been stipulated to ensure safe human consumption of animal products (e.g., milk/meat). Analysis of injection sites can provide useful consumer safety information since numerous compounds can accumulate at such sites, which are a first and often repeated point of administration [218]. Indeed, almost 30\% of injection sites sampled and analyzed from rendered animals at a slaughterhouse in Belgium contained residues of a veterinary product above the established maximum residue limits [219]. Since there are commonly a limited number of possible injection sites, it should be relatively straightforward to determine and verify these locations for sampling (of a field carcass, for example). Following injection, pharmaceuticals rapidly diffuse to the bloodstream or the lymphatic capillaries [218] and analysis of injection sites can provide information about recently administered compounds. Alternatively, where a carcass has been stripped clean by scavengers and only the hide remains, likely injection sites can still be identified and a topical skin/ hair analysis can be conducted.

\section{Recommended exploration of ingesta/vomitus/gastric contents and pellets}

Gastric contents are typically examined during post-mortem (http:// www.tiaft.org/node/86) to determine what/where the decedent last ate, provide a greater sense of relevant activities and whereabouts prior to death, and sometimes estimate time since death [220,221]. Stomach contents can also be analyzed for poisons/toxicants [222]. In suspected wildlife poisoning cases, the decedent's last meal, and its provenance usually established via DNA testing - can be of huge significance. Indeed, in southern Spain, the stomach contents and vomit of wildlife have also been routinely analyzed in suspected wildlife poisoning cases (Consejeria de Medio Ambiente, unpublished data). In wildlife, regurgitation of ingested matter is often associated with exposure to an acute poison and is particularly telling when observed in birds of prey [24]. This fact and this sample matrix are both noteworthy because debilitation or mortality arising from exposure to an acutely toxic agent - typically a bait laced with poison - may overshadow the presence of other relevant residues (e.g., of NSAIDs) in the bait itself which would indicate chronic use/exposure. As such, we argue that when available, ingesta/gastric contents (particularly bait material recovered in the stomach of the deceased) should be routinely screened for NSAIDs and other veterinary agents of concern, to begin to gain a sense of local veterinary practices.

Numerous avian species regurgitate pellets (e.g., owls and vultures), and the viability of this sample in toxicant/contaminant monitoring should be further explored. For example, in 2006, an adult cinereous vulture (Aegypius monachus) observed in a debilitated condition was captured from the wild and submitted to a rehabilitation facility in Spain. A blood sample revealed cholinesterase inhibition, symptomatic of exposure to an organophosphorus or carbamate compound [24]. However, more specific information was required to treat the bird and prepare a case against the offender(s). A pellet recovered with the vulture tested positive for chlorfenvinphos, and this result helped to secure a stiff penalty against a gamekeeper, while the vulture recovered and was eventually released [223]. We therefore recommend evaluating whether NSAIDs (and other veterinary agents of concern) can be detected in pellets, particularly as a non-invasive means of monitoring their presence within the agricultural environment. 
Citation: Richards NL, Hall SW, Harrison NM, Gautam L, Scott KS, et al. (2014) Merging Wildlife and Environmental Monitoring Approaches with Forensic Principles: Application of Unconventional and Non-Invasive Sampling in Eco-Pharmacovigilance. J Forensic Res 5: 228. doi: $10.4172 / 2157-7145.1000228$

Page 10 of 16

\section{A note about scavenging and coprophagous insects: exposure risks and viability as samples}

As previously discussed, assemblages of scavenging insects perform a vital ecosystem service by helping to break down carcasses [224]. Their activity affects the rate of carcass/cadaver decomposition, and hence represents an important factor in estimating time since death [224-227]. Illicit parent drug and/or metabolites have been detected in insect larvae recovered from cadavers $[21,227]$ and such exposure has been shown to slow larval growth [225,227]. Similarly, residues of carbofuran (and one of its metabolites) have been found in deceased blue bottle flies (Calliphora vomitoria) recovered from an animal carcass in Spain (Consejeria de Medio Ambiente, unpublished data). We are unaware of any studies that have investigated the potential exposure of scavenging insects to nonsteroidal anti-inflammatory drugs, or possible secondary exposure/effects to the species that feed on them. In contrast to scavenging insects, a substantial number of studies have examined the repercussions of veterinary agents excreted in livestock animal dung to coprophagous insect species [186,228] which play a key role in maintaining pasture hygiene [229] and productivity, and in cycling nutrients [183]. However, to our knowledge, the potential exposure of these species to NSAIDs has not yet been evaluated. Given the real possibility that NSAIDs may be chronically present in livestock carcasses and dung available to scavenging and coprophagous insects in agricultural/farming sectors, we strongly recommend further investigation of exposure risks to both species, in conjunction with dung analysis.

\section{Conclusion}

Special emphasis was placed on hair, wool and feathers with additional consideration given to fecal matter, eyes and ocular material, bone matter, injection sites, ingesta/gastric/contents/pellets and scavenging/coprophagous insects. We also highlighted a number of circumstances where the presence of a potentially chronically toxic veterinary agent could be missed (e.g., when cause of death arises from exposure to an acute toxin). Irrespective of cause of death, we recommend that existing wildlife monitoring archives are more routinely screened for pharmaceuticals of concern (i.e., NSAIDs) as they often are for better recognized environmental contaminants (i.e., heavy metals, POPs).

\section{Acknowledgements}

The authors appreciate this opportunity to discuss promising research avenues for further exploration and development. Earlier versions of this manuscript were significantly improved by feedback from Mark Taggart. Comments from Mary Burnham-Curtis, Antoni Margalida and Natasha Kreitals were also appreciated. Chris Bowden provided a number of integral references and Deb Tirmenstein's help with manuscript preparation was invaluable. We also acknowledge the support of Anglia Ruskin University, Department of Life Sciences, which allowed us to pursue the analyses detailed herein. N. Richards dedicates this review to K9 Tsavo (2001-2013) for a decade of outstanding service in non-invasive monitoring.

\section{References}

1. Dmowski K (1999) Birds as bioindicators of heavy metal pollution: review and examples concerning European species. Acta Ornithol 34: $1-25$.
2. Fletcher M, Barnett L (2003) Bee pesticide poisoning incidents in the United Kingdom. Bull Insectol 56: 141-145.

3. Furness RW (2010) Birds as Monitors of Mercury Pollution. In: Newman M.C. (Ed.), Fundamentals of Ecotoxicology, (third edn.) CRC Press, Boca Raton, FL: 137-142.

4. Hebert CE, Weseloh DVC (2003) Assessing temporal trends in contaminants from long-term avian monitoring programs: the influence of sampling frequency. Ecotoxicology 12: 141-151.

5. Holt EA, Miller SW (2011) Bioindicators: Using organisms to measure environmental impacts. Nature Education Knowledge 3:8.

6. Sainsbury AW, Kirkwood JK, Bennett PM, Cunningham AA (2001) Status of wildlife monitoring in the United Kingdom. Vet Rec 148: 558-563.

7. Talmage SS, Walton BT (1991) Small mammals as monitors of environmental contaminants. Rev Environ Contam Toxicol 119: 47-145.

8. Vander Pol SS, Becker PR (2007) Monitoring contaminants in seabirds: the importance of specimen banking. Marine Ornithology 35: 113-118.

9. Wren CD (1986) Mammals as biological monitors of environmental metal levels. Environ Monit Assess 6: 127-144.

10. Basu N, Scheuhammer AM, Bursian SJ, Elliott J, Rouvinen-Watt K, et al. (2006) Mink as a sentinel species in environmental health. Environ Res 103: 130-144.

11. Anderson HM, McCafferty DJ, Saccheri IJ, McCluskie AE (2006) Noninvasive genetic sampling of the Eurasian otter (Lutra lutra) using hairs. Hystrix It J Mamm 17: 65-77.

12. Guertin DA, Harestad AS, Ben-David M, Drouillard KG, Elliott J (2009) Fecal genotypics and contaminant analyses reveal variation in individual river otter exposure to localized persistent contaminants. Environ Toxicol Chem 29: 275-284.

13. Duggan JM, Heske EJ, Schooley RL, Hurt A, Whitelaw A (2011) Comparing detection dog and livetrapping surveys for a cryptic rodent. J Wildl Manage 75: 1209-1217.

14. Long R, Donovan TM, Mackay P, Zielinski WJ, Buzas JS (2007) Effectiveness of scat detection dogs for detecting forest carnivores. J Wildl Manage 71: 2007-2017.

15. Rodgers TW, Janečka, JE (2013) Applications and techniques for noninvasive faecal genetics research in felid conservation. Eur J Wildl Res 59: 1-16.

16. Woollett (Smith) DA, Hurt A, Richards NL (2013) The Current and Future Roles of Free-ranging Detection Dogs in Conservation Efforts. In: Gompper M.E. (Ed.), Free-ranging Dogs and Wildlife Conservation. Oxford University Press, Oxford, UK. Chapter 10: 239-264.

17. Steyer K, Simon O, Kraus RHS, Haase P, Nowak C (2013) Hair trapping with valerian-treated lure sticks as a tool for genetic wildcat monitoring in low-density habitats. Eur J Wildl Res 59: 39-46.

18. Darimont CT, Reimchen, TE, Bryan HM, Paquet PC (2008) Faecalcentric approaches to wildlife ecology and conservation; methods, data and ethics. Wildl Biol Pract 4: 73-87.

19. Farnsworth EJ, Rosovsky J (1993) The ethics of ecological field experimentations. Cons Biol 7: 463-472.

20. Brook RK, Kutz, SJ, Veitch, AM, Popko RA, Elkin BT (2009) Fostering community-based wildlife health monitoring and research in the Canadian North. EcoHealth 6: 266-278.

21. Drummer OH, Gerostamoulos J (2002) Postmortem drug analysis: analytical and toxicological aspects. Ther Drug Monit 24: 199-209.

22. Goddard KW (2005) Veterinary Aspects of Forensic Medicine, Wild Animals. In: Encyclopedia of Forensic and Legal Medicine. Elsevier, Ltd., 344-349.

23. Watterson J (2006) Challenges in forensic toxicology of skeletonised human remains. Analyst 131: 961-965.

24. Mineau P, Porter S, Meteyer CU (2012) Carbofuran: Toxicity, Diagnosing Poisoning and Rehabilitation of Poisoned Birds. In: Richards N.L. (Ed.), Carbofuran and Wildlife Poisoning: Global Perspectives and Forensic Approaches. John Wiley \& Sons, Inc., Chichester, UK. Chapter 2: $19-30$. 
Citation: $\quad$ Richards NL, Hall SW, Harrison NM, Gautam L, Scott KS, et al. (2014) Merging Wildlife and Environmental Monitoring Approaches with Forensic Principles: Application of Unconventional and Non-Invasive Sampling in Eco-Pharmacovigilance. J Forensic Res 5: 228. doi: $10.4172 / 2157-7145.1000228$

Page 11 of 16

25. de Almeida A, de Almeida AF (2012) A Latin American Perspective: The Environmental Impact of Farming Wheat and Rice Treated With Carbofuran and Rhodamine B on Brazilian Wild Birds. In: Richards N.L. (Ed.), Carbofuran and Wildlife Poisoning: Global Perspectives and Forensic Approaches. John Wiley \& Sons, Inc., Chichester, UK. Chapter $7: 189-207$.

26. Ashton D, Hilton M, Thomas KV (2004) Investigating the environmental transport of human pharmaceuticals to streams in the United Kingdom. Sci Total Environ 333: 167-184.

27. Al-Rajab AJ, Sabourin L, Lapen DR, Topp E (2010) The non-steroidal anti-inflammatory drug diclofenac is readily biodegradable in agricultural soils. Sci Total Environ 409: 78-82.

28. Knopp D, Deng A, Letzel M, Taggart MA, Himmelsbach M, Zhu Q, et al. (2007) Immunological Determination of the Pharmaceutical Diclofenac in Environmental and Biological Samples. In: Kennedy, I. R. (Ed.), Rational Environment Management of Agrochemicals: Risk Assessment, Monitoring, and Remedial Action. ACS Symposium Series, Oxford University Press, Oxford, UK. Chapter 13: 203-226.

29. Kosjeka T, Heath E, Krbavčič A (2005) Determination of non-steroidal anti-inflammatory drug (NSAIDs) residues in water samples. Environ Int 31: 679- 685 .

30. Láng, J, Köhidai L (2012) Effects of the aquatic contaminant human pharmaceuticals and their mixtures on the proliferation and migratory responses of the bioindicator freshwater ciliate Tetrahymena. Chemosphere 89: 592-601.

31. Migowska N, Caban M, Stepnowski P, Kumirska J (2012) Simultaneous analysis of non-steroidal anti-inflammatory drugs and estrogenic hormones in water and wastewater samples using gas chromatographymass spectrometry and gas chromatography with electron capture detection. Sci Total Environ 441: 77-88.

32. Ortiz de García S, Pinto GP, García-Encina PA, Mata RI (2013) Ranking of concern, based on environmental indexes, for pharmaceutical and personal care products: an application to the Spanish case. J Environ Manage 129: 384-397.

33. Santos LH, Araújo AN, Fachini A, Pena A, Delerue-Matos C, et al. (2010) Ecotoxicological aspects related to the presence of pharmaceuticals in the aquatic environment. J Hazard Mater 175: 45-95.

34. $\mathrm{Xu} \mathrm{J,} \mathrm{Wu} \mathrm{L,} \mathrm{Chen} \mathrm{W,} \mathrm{Chang} \mathrm{AC} \mathrm{(2010)} \mathrm{Leaching} \mathrm{potential} \mathrm{of}$ nonsteroidal anti-inflammatory drugs in soils. Environ Toxicol Chem 29: 800-807.

35. Zhao JL, Ying GG, Liu YS, Chen F, Yang, JF, et al. (2010) Occurrence and a screening-level risk assessment of human pharmaceuticals in the Pearl River system, South China. Environ Toxicol Chem 29: 1377-1384.

36. Behara SK, Kim HW, Oh JE, Park HS (2011) Occurrence and removal of antibiotics, hormones and several other pharmaceuticals in wastewater treatment plants of the largest industrial city of Korea. Sci Total Environ 409: 4351-4360.

37. Jelić A, Gros M, Petrović M, Ginebreda A, Barceló D (2012) Occurrence and Elimination of Pharmaceuticals During Conventional Wastewater Treatment. In: Guasch, H, Ginebrada, A, Geiszinger A (Eds.), Emerging and Priority Pollutants in Rivers, The Handbook of Environmental Chemistry. Springer-Verlag, Berlin: 1-23.

38. Kotsouba V, Heberer T, Fuhrmann B, Schmidt-Naumler K, Tsipi D, et al. (2003) Determination of polar pharmaceuticals in sewage water of Greece by gas chromatography-mass spectrometry. Chemosphere 51: 69-75.

39. Verenitch SS, Lowe CJ, Mazumder A (2006) Determination of acidic drugs and caffeine in municipal wastewaters and receiving waters by gas chromatography-ion trap tandem mass spectrometry. J Chromatogr A 1116: 193-203.

40. Gómez MJ, Agüera, A, Mezcua M, Hurtado J, Mocholí F, et al. (2007) Simultaneous analysis of neutral and acidic pharmaceuticals as well as related compounds by gas chromatography-tandem mass spectrometry in wastewater. Talanta 73: 314-320.
41. Minetto L, Mayer FM, Mallmann CA, Martins AF (2012) Quantification of diclofenac in hospital effluent and identification of metabolites and degradation products. Clean-Soil, Air, Water 40: 950-957.

42. Ferrari B, Paxéus N, Giudice RL, Pollio A, Garric J (2003) Ecotoxicological impact of pharmaceuticals found in treated wastewaters: study of carbamazepine, clofibric acid, and diclofenac. Ecotox Environ Safe 55: 359-370.

43. Metcalfe CD, Miao XS, Koenig BG, Struger J (2003) Distribution of acidic and neutral drugs in surface waters near sewage treatment plants in the lower Great Lakes Canada. Environ Toxicol Chem 22: 2881-2889.

44. Paxéus N (2004) Removal of selected NSAIDs, gemfibrozil, carbamazepine, $ß$-blockers, trimethoprim and triclosan in conventional wastewater treatment plants in five EU countries and their discharge to the aquatic environment. Water Sci Technol 50: 253-260.

45. Zhang Y, Geißen SU, Gal C (2008) Carbamazepine and diclofenac: removal in wastewater treatment plants and occurrence in water bodies. Chemosphere 73: 1151-1161.

46. Boxall ABA (2010) Veterinary Medicines and the Environment. In: Elliott, J., Lees, P. (Eds.), Comparative and Veterinary Pharmacology. Springer-Verlag, Berlin.

47. Orlando EF, Kolok AS, Binzcik GA, Gates JL, Horton MK, et al. (2004) Endocrine-disrupting effects of cattle feedlot effluent on an aquatic sentinel species, the fathead minnow. Environ Health Perspect 112: 353-358.

48. Kopcha M1, Kaneene JB, Shea ME, Miller R, Ahl AS (1992) Use of nonsteroidal anti-inflammatory drugs in food animal practice. J Am Vet Med Assoc 201: 1868-1872.

49. Lees P1, Landoni MF, Giraudel J, Toutain PL (2004) Pharmacodynamics and pharmacokinetics of nonsteroidal anti-inflammatory drugs in species of veterinary interest. J Vet Pharmacol Ther 27: 479-490.

50. Navarre CB (2006) Prudent Use of Pain Relief in Food Animals. 38th Proceedings of the American Association of Bovine Practitioners. 50-52.

51. Schwartzkopf-Genswein KS, Fierheller EE, Caulkett NA, Janzen ED, Pajor EA, et al. (2012) Achieving pain control for routine management procedures in North American beef cattle. Animal Frontiers 2: 52-58.

52. Smith GW1, Davis JL, Tell LA, Webb AI, Riviere JE (2008) Extralabel use of nonsteroidal anti-inflammatory drugs in cattle. J Am Vet Med Assoc 232: 697-701.

53. Cleuvers M (2004) Mixture toxicity of the anti-inflammatory drugs diclofenac, ibuprofen, naproxen, and acetylsalicylic acid. Ecotoxicol Environ Saf 59: 309-315.

54. Jones OA1, Voulvoulis N, Lester JN (2002) Aquatic environmental assessment of the top 25 English prescription pharmaceuticals. Water Res 36: 5013-5022.

55. Ternes TA (1998) Occurrence of drugs in German sewage treatment plants and rivers. Water Res 32: 3245-3260.

56. Thomas KV, Hilton MJ (2004) The occurrence of selected human pharmaceutical compounds in UK estuaries. Mar Pollut Bull 49: 436-444.

57. Han S, Choi K, Ji K, Kim S, Ahn B, et al. (2010) Endocrine disruption and consequences of chronic exposure to ibuprofen in Japanese medaka (Oryzias latipes) and freshwater cladocerans Daphnia magna and Moinamacrocopa. Aquat Toxicol 98: 256-264.

58. Hoeger B1, Köllner B, Dietrich DR, Hitzfeld B (2005) Water-borne diclofenac affects kidney and gill integrity and selected immune parameters in brown trout (Salmotrutta f. fario). Aquat Toxicol 75: 53-64.

59. Kallio JM1, Lahti M, Oikari A, Kronberg L (2010) Metabolites of the aquatic pollutant diclofenac in fish bile. Environ Sci Technol 44: 7213-7219.

60. Memmert U, Peither A, Burri R, Weber K, Schmidt T, et al. (2013) Diclofenac: New data on chronic toxicity and bioconcentration in fish. Environ Toxicol Chem 32: 442-452.

61. Schwaiger J, Ferling H, Mallow U, Wintermayr H, Negele RD (2004) Toxic effects of the non-steroidal anti-inflammatory drug diclofenac. 
Citation: $\quad$ Richards NL, Hall SW, Harrison NM, Gautam L, Scott KS, et al. (2014) Merging Wildlife and Environmental Monitoring Approaches with Forensic Principles: Application of Unconventional and Non-Invasive Sampling in Eco-Pharmacovigilance. J Forensic Res 5: 228. doi: $10.4172 / 2157-7145.1000228$

Page 12 of 16

Part I: histopathological alterations and bioaccumulation in rainbow trout. Aquat Toxicol 68: 141-150.

62. van den Brandhof EJ, Montforts M (2010) Fish embryo toxicity of carbamazepine, diclofenac and metoprolol. Ecotoxicol Environ Saf 73: 1862-1866.

63. Basu N, Head J, Scheuhammer AM, Bursian SJ, Rouvinen-Watt K, et al. (2009) The mink is still a reliable sentinel species in environmental health. Environ Res 109: 940-941.

64. Foley RE, Jackling S.J, Sloan R.J, Brown MK (1988) Organochlorine and mercury residues in wild mink and otter: comparison with fish. Environ Toxicol Chem 7: 363-374.

65. Grove RA, Henny CJ, Kaiser JL (2009) Osprey: worldwide sentinel species for assessing and monitoring environmental contamination in rivers, lakes, reservoirs, and estuaries. J Toxicol Environ Health Part B 12: 25-44.

66. Langner HW, Greene E, Domenech R, Staats MF (2011) Mercury and other mining related contaminants in ospreys along the upper Clark Fork River, Montana, USA. Arch Environ Contam Toxicol 62: 681-695.

67. Lemarchand C, Rosoux R, Berny P (2011) Semi Aquatic Top-predators as Sentinels of Diversity and Dynamics of Pesticides in Aquatic Food Webs, The case of European Otter (Lutra lutra) and Osprey (Pandion haliaetus) in Loire River Catchment, France. In: Stoytcheva M. (Ed.), Pesticides in the Modern World: Risks and Benefits. InTech, Croatia. Chapter 16: 289-310.

68. Mason CF, Madsen AB (1993) Organochlorine pesticide residues and PCBs in Danish otters (Lutra lutra). Sci Total Environ 133: 73-81.

69. Persson S (2007) The mink (Mustela vison) as an indicator of environmental reproductive toxicity, Undergraduate Thesis, Swedish University of Agricultural Sciences, Sweden.

70. Simpson VR, Bain M, Brown R, Brown B, Lacy R (2000) A long-term study of vitamin A and polychlorinated hydrocarbon levels in otters (Lutra lutra) in south west England. Environ Pollut 110 :267-275.

71. Wren CD (1991) Cause-effect linkages between chemicals and populations of mink (Mustela vison) and otter (Lutra canadensis) in the Great Lakes basin. J Toxicol Environ Health 33: 549-585.

72. Bowman J, Schulte-Hostedde AI (2009) The mink is not a reliable sentinel species. Environ Res 109: 937-939.

73. Reid N, Thompson D, Haydena B, Marnell F, Montgomery WI (2013) Review and quantitative meta-analysis of diet suggests the Eurasian otter (Lutra lutra) is likely to be a poor bioindicator. Ecol Indic 26: 5-13.

74. Bowman J, Kidd AG, Martin PA, McDaniel TV, Nituch LA, et al. (2012) Testing for bias in a sentinel species: Contaminants in free-ranging domestic, wild, and hybrid mink. Environ Res 112: 77-82.

75. Toutain PL, Ferran A, Bousquet-Mélou A (2010) Species differences in pharmacokinetics and pharmacodynamics. Handb Exp Pharmacol 199: $19-48$.

76. Simpson VR (1997) Health status of otters (Lutra lutra) in south west England based on postmortem findings. Vet Rec 141: 91-97.

77. Simpson VR (2007) Health status of otters in southern and south west England 1996-2003. Science Report SCO10064/SR1, Bristol (UK), Environment Agency.

78. Simpson VR, Tomlinson AJ, Molenaar FM, Lawson B, Rogers KD (2011) Renal calculi in wild Eurasian otters (Lutra lutra) in England. Vet Rec 169: 49-54.

79. Richards NL, Cook G, Simpson V, Hall S, Harrison N, et al. (2011) Qualitative detection of the NSAIDs diclofenac and ibuprofen in the hair of Eurasian otters (Lutra lutra) occupying UK waterways with GC-MS. Eur J Wildl Res 57: 1107-1114.

80. Richards N, Hall S, Scott K, Harrison N (2011) First detection of an NSAID, flunixin, in sheep's wool using GC/MS. Environ Pollut 159: 1446-1450.

81. Elliott JE, Guertin DA, Balke JME (2008) Chlorinated hydrocarbon contaminants in feces of river otters from the southern Pacific coast of Canada, 1998-2004. Sci Total Environ 397: 58-71.
82. Guertin DA, Ben-David M, Harestad AS, Elliott JE (2012) Fecal genotyping reveals demographic variation in river otters inhabiting a contaminated environment. J Wildl Manage 76: 1540-1550.

83. Şekercioğlu CH, Daily GC, Ehrlich P (2004) Ecosystem consequences of bird declines. Proc Natl Acad Sci USA 101: 18042-18047.

84. Reeves N (2009) Taphonomic effects of vulture scavenging. J Forensic Sci 54: 523-528.

85. Spradley MK, Hamilton MD, Giordano A (2011) Spatial patterning of vulture scavenged human remains. Forensic Sci Int 219: 57-63.

86. Green RE, Taggart MA, Das D, Pain DJ, Kumar CS, et al. (2006) Collapse of Asian vulture populations: risk of mortality from residues of the veterinary drug diclofenac in carcasses of treated cattle. J Appl Ecol 43: 949-956.

87. Oaks JL, Gilbert M, Virani MZ, Watson RT, Meteyer CU, et al. (2004) Diclofenac residues as the cause of vulture population decline in Pakistan. Nature 427: 630-633.

88. Prakash V, Bishwakarma MC, Chaudhary A, Cuthbert R, Dave R, et al. (2012) The population decline of Gyps vultures in India and Nepal has slowed since veterinary use of diclofenac was banned. PLoS ONE 7: e49118.

89. Ogada D (2014) The power of poison: pesticide poisoning of Africa's wildlife. Ann NY Acad Sci Apr 9 doi: 10.1111/nyas.12405 [Epub ahead of print].

90. Virani, MZ, Kendall C, Njoroge P, Thomsett S (2010) Major declines in the abundance of vultures and other scavenging raptors in and around the Masai Mara ecosystem, Kenya. Biol Cons 144: 746-752.

91. Pain DJ, Bowden CGR., Cunningham AA, Cuthbert R, Das D, et al. (2008) The race to prevent the extinction of South Asian vultures. Bird Cons Int. 18: S30-S48.

92. Swan G, Naidoo V, Cuthbert R, Green RE, Pain DJ, et al. (2006) Removing the threat of diclofenac to critically endangered Asian vultures. PLoSBiol 4: 395-402.

93. Swarup D, Patra RC, Prakash V, Cuthbert R, Das D, et al. (2007) Safety of meloxicam to critically endangered Gyps vultures and other scavenging birds in India. Animal Cons 10: 192-198.

94. Cuthbert RJ, Dave R, Chakraborty SS, Kumar S, Prakash S, et al. (2011a) Assessing the ongoing threat from veterinary non-steroidal antiinflammatory drugs to critically endangered Gyps vultures in India. Oryx 45: $420-426$.

95. Cuthbert RJ, Prakash V, Saini M, Upreti S, Swarup D, et al. (2011b) Are conservation actions reducing the threat to India's vulture populations? Curr Sci (India) 101: 1480-1484.

96. Taggart MA, Cuthbert R, Das D, Sashikumar C, Pain DJ, et al. (2007a) Diclofenac disposition in Indian cow and goat with reference to Gyps vulture population declines. Environ Pollut 147: 60-65.

97. Taggart MA, Senacha KR, Green RE, Jhala YV, Raghavan B, et al. (2007b) Diclofenac residues in carcasses of domestic ungulates available to vultures in India. Environ Int 33: 759-765.

98. Cuthbert R, Taggart MA, Prakash V, Saini M, Swarup D, et al.(2011c) Effectiveness of action in India to reduce exposure of Gyps vultures to the toxic veterinary drug diclofenac. Plos ONE 6: e19069.

99. Taggart MA, Senacha KR, Green RE, Cuthbert R, Jhala YV, et al. (2009) Analysis of nine NSAIDs in ungulate tissues available to critically endangered vultures in India. Environ Sci Technol 43: 4561-4566.

100. Gilbert M, Watson RT, Ahmed S, Asim M, Johnson JA (2007) Vulture restaurants and their role in reducing diclofenac exposure in Asian vultures. Bird Cons Int 17: 63-77.

101. Hernández M, Margalida A (2009) Poison-related mortality effects in the endangered Egyptian vulture population in Spain. Eur J Wildl Res 55: 415-423.

102. Margalida A, Bertran J, Heredia R (2009) Diet and food preferences of the endangered bearded vulture: A basis for their conservation. Ibis 151: 235-243.

103. Fajardo I, Ruiz A, Zorilla-Delgado I, Valero A, Fernandez I, et al. (2012) Use of Specialised Canine Units to Detect Poisoned Baits and Recover 
Citation: $\quad$ Richards NL, Hall SW, Harrison NM, Gautam L, Scott KS, et al. (2014) Merging Wildlife and Environmental Monitoring Approaches with Forensic Principles: Application of Unconventional and Non-Invasive Sampling in Eco-Pharmacovigilance. J Forensic Res 5: 228. doi: $10.4172 / 2157-7145.1000228$

Page 13 of 16

Forensic Evidence in Andalucía (Southern Spain). In: Richards N.L. (Ed.), Carbofuran and Wildlife Poisoning: Global Perspectives and Forensic Approaches. John Wiley \& Sons, Inc. Chichester, UK. Chapter 5: $147-155$.

104. Donázar JA, Margalida A, Carrete M, Sánchez-Zapata JA (2009) Too sanitary for vultures. Sci 326: 664 .

105. Margalida A, Colomer M (2012) Modelling the effects of sanitary policies on European vulture conservation. Scientific Reports 2: 753.

106. Camiña A, Yosef R (2012) Effect of European Union BSE-related enactments on fledgling Eurasian Griffons Gyps fulvus. Acta Ornithol 47: 101-109.

107. Zuberogoitia I, González-Oreja JA, Martínez JE, Zabala J, Gómez I, et al. (2013) Foraging movements of Eurasian griffon vultures Gyps fulvus: Implications for supplementary feeding management. Eur J Wildl Res 59: 421-429.

108. Margalida A, Donázar JA, Carrete M, Sánchez-Zapata JA, (2010) Sanitary versus environmental policies: Fitting together two pieces of the puzzle of European vulture conservation. J Appl Ecol 47: 931-93.

109. Blanco G, Lemus JÁ, Martínez F, Arroyo B, García-Montijano M, et al. (2009) Ingestion of multiple veterinary drugs and associated impact on vulture health: Implications of livestock carcass elimination practices. Animal Con 12 : 571-580.

110. Blanco G, Lemus JÁ (2010) Livestock drugs and disease: The fatal combination behind breeding failure in endangered bearded vultures. PLoS ONE 5: e14163.

111. Lemus JÁ, Blanco G, Grande J, Arroyo B, Garcia-Montijano M, et al. (2008) Antibiotics threaten wildlife: circulating quinolone residues and disease in avian scavengers. PLoS ONE 3: e1444.

112. Cuthbert R, Parry-Jones J, Green R, Pain DJ (2007) NSAIDs and scavenging birds: Potential impacts beyond Asia's critically endangered vultures. Biol Lett 3: 91-94.

113. Naidoo V, Wolter K, Cromarty D, Diekmann M, Duncan N, et al. (2009) Toxicity of nonsteroidal anti-inflammatory drugs to Gyps vultures: A new threat from ketoprofen. Biol Lett 6: 339-341.

114. Naidoo V, Venter L, Wolter K, Taggart M, Cuthbert R (2010) The toxicokinetics of ketoprofen in Gyps coprotheres: Toxicity due to zeroorder metabolism. Arch Toxicol 8410: 761-766.

115. Kintz P (2004) Value of hair analysis in postmortem toxicology. Forensic Sci Int 142: 127-134.

116. Boumba VA, Ziavrou KS, Vougiouklakis T (2006) Hair as a biological indicator of drug use, drug abuse or chronic exposure to environmental toxicants. Int J Toxicol 25:143-163.

117. Nakahara Y (1999) Hair analysis for abused and therapeutic drugs. J Chromatogr B 733: 161-180.

118. Dulaurent S, Gaulier JM, Baudel JL, Fardet L, Maury E, et al. (2007) Hair analysis to document non-fatal pesticide intoxication cases. Forensic Sci Int $176: 72-75$.

119. Gaillard Y, Pépin G (1999) Testing hair for pharmaceuticals. J Chromatogr B 733: 231-246.

120. Richards NL (2010) Detection of nonsteroidal anti-inflammatory drugs in hair, nails and feathers using GC-MS, with emphasis on diclofenac, a forensic tool for wildlife conservation. Ph.D. Dissertation. Anglia Ruskin University, Cambridge, UK.

121. Stenn KS, Paus R (2001) Controls of hair follicle cycling. Physiol Rev 81: 449-494.

122. Harkey MR (1993) Anatomy and physiology of hair. Forensic Sci Int 63: 9-18.

123. Henderson GL (1993) Mechanisms of drug incorporation into hair. Forensic Sci Int 63: 19-29.

124. Cone EJ, Joseph R (1996) The Potential for Bias in Hair Testing for Drugs of Abuse. In: Kintz P. (Ed.), Drug Testing in Hair. CRC Press, Boca Raton, FL: 69-93.

125. Rollins DE, Wilkins DG, Krueger GG, Augsburger MP, Mizuno A, et al. (2003) The effect of hair color on the incorporation of codeine into human hair. J Anal Toxicol 27: 545-551.
126. Rothe M, Pragst F, Thor, Hunger J (1997) Effect of pigmentation on the drug deposition in hair of grey-haired subjects. Forensic Sci Int 84: 53-60.

127. Engelhart DA, Jenkins AJ (2002) Detection of cocaine analytes and opiates from post-mortem cases. J Anal Toxicol 26: 489-492.

128. Lin DL, Yin RM, Liu HC, Wang CY, Liu RH (2004) Deposition characteristics of methamphetamine and amphetamine in fingernail clippings and hair sections. J Anal Toxicol 28: 411-417.

129. Nakahara Y, Kikura R, Takahashi K (1998) Hair analysis for drugs of abuse XX: incorporation and behaviors of seven methamphetamine homologs in the rat hair root. Life Sciences 63: 883-893.

130. Fente CA, Vásquez BI, Franco C, Cepeda A, Gigosos PG (1999) Determination of clenbuterol residues in bovine hair by using diphasic dialysis and gas chromatography - mass spectrometry. J Chromatogr B 726: 133-139.

131. Gaillard Y, Balland A, Doucet F, Pépin G (1997) Detection of illegal clenbuterol use in calves using hair analysis: Application in meat quality control. J Chromatogr B 703: 85-95.

132. Hernández-Carrasquilla $M$ (2002) External contamination of bovine hair with $ß 2$-agonist compounds: Evaluation of decontamination strategies. J Chromatogr B 767: 235-243.

133. Popot MA, Stojiljkovic N, Garcia P, Richard CA, Bonnaire Y, et al. (2003) Additional Studies on the Detection of Drugs in Horse Hair Samples. Proceedings of the 14th International Conference of Racing Analysis and Veterinarians: 115-120.

134. Frandson RD, Wilke WL, Fails AD (2003) Anatomy and Physiology of Farm Animals, (sixth edn). Lippincott Williams \& Wilkins, Baltimore, MD.

135. Hopps HC (1977) The biologic bases for using hair and nail for analyses of trace elements. Sci Total Environ 7: 71-89.

136. Fisher P (1999) Review of using Rhodamine B as a marker for wildlife studies. Wildl Soc Bull 27:318-329.

137. Gunaratram P, Wilkinson GT (1983) A study of normal hair growth in the dog. J Small Anim Pract 24: 445-453.

138. Messenger AG (1993) The control of hair growth: An overview. J Invest Dermatol (Suppl) 101: 4S-9S.

139. Galbraith $H$ (1998) Nutritional and hormonal regulation of hair follicle growth and development. Proc Nutr Soc 57: 195-205.

140. Popot MA, Boyer S, Maciejewski P, Garcia D, Dehennin L, et al. (2001) Approaches to the Detection of Drugs in Horse Hair. Proceedings of the 13th International Conference of Racing Analysis and Veterinarians: 115-120.

141. Henny CJ, Blus LJ, Kolbe EJ, Fitzner RE (1985) Organophosphate insecticide (famphur) topically applied to cattle kills magpies and hawks. J Wildl Manage 49: 648-658.

142. Henny CJ, Kolbe EJ, Hill EF, Blus LJ (1987) Case histories of bald eagles and other raptors killed by organophosphorus insecticides topically applied to livestock. J Wildl Dis 23: 292-295.

143. Evans D (2007a) Wool residues - market, environmental and occupational health issues. FarmNote 271, Department of Agriculture and Food of Western Australia.

144. Evans D (2007b) Sheep lice - selective chemical treatment. FarmNote 274. Department of Agriculture and Food of Western Australia.

145. Wardhaugh KG, Holter P, Longstaff (2001) The development and survival of three species of coprophagous insect after feeding on the faeces of sheep treated with controlled-release formulations of ivermectin or albendazole. Aust Vet J 79: 125-32.

146. Burger J (1993) Metals in avian feathers: Bioindicators of environmental pollution. Rev Environ Toxicol 5: 203-311.

147. Battaglia A, Ghidini S, Campanini G, Spaggiar S (2005) Heavy metal contamination in little owl (Athene noctua) and common buzzard (Buteo buteo) from northern Italy. Ecotoxicol Environ Saf 60: 61-66.

148. Condon AM, Cristol DA (2009) Feather growth influences blood mercury level of young songbirds. Environ Toxicol Chem 28: 395-401.

149. Adout A, Hawlena D (2007) Determination of trace elements in pigeon and raven feathers by ICPMS. Int J Mass Spectrom 267: 109-116. 
Citation: Richards NL, Hall SW, Harrison NM, Gautam L, Scott KS, et al. (2014) Merging Wildlife and Environmental Monitoring Approaches with Forensic Principles: Application of Unconventional and Non-Invasive Sampling in Eco-Pharmacovigilance. J Forensic Res 5: 228. doi: $10.4172 / 2157-7145.1000228$

Page 14 of 16

150. Burger J, Gochfeld M (2004) Marine birds as sentinels of environmental pollution. Eco Health 1: 263-274.

151. Dauwe T, Bervoets L, Pinxten R, Blust R, Eens M (2003) Variation of heavy metals within and among feathers of birds of prey: Effects of molt and external contamination. Environ Pollut 124: 429-436.

152. Furness RW, Muirhead SJ, Woodburn M (1986) Using bird feathers to measure mercury in the environment: relationships between mercury content and moult. Marine Poll Bull 17: 27-30.

153. Nighat S, Iqbal S, Nadeem M.S, Mahmood T, Shah SI (2013) Estimation of heavy metal residues from the feathers of Falconidae, Accipitridae, and Strigidae in Punjab, Pakistan. Turk J Zool 37: 488-500.

154. Pain DJ, Meharg AA, Ferrer M, Taggart M, Penteriani V (2005) Lead concentrations in bones and feathers of the globally threatened Spanish imperial eagle. Biol Conserv 121: 603-610.

155. Wiemeyer SN, Jurek RM, Moore JF (1986) Environmental contaminants in surrogates, foods, and feathers of California condors (Gymnogyps californicus). Environ Monit Assess 6: 91-111.

156. Wiemeyer SN, Scott JM, Anderson MP, Bloom PH, Stafford CJ (1998) Environmental contaminants in California condors. J Wildl Manage 52: 238-247.

157. Fry M (2004) Final report addendum: analysis of lead in California condor feathers: Determination of exposure and depuration during feather growth. Species Conservation and Recovery Program Report, 2004-02. California Department of Fish and Game.

158. Chandler RM, Pyle P, Flannery ME, Long DJ, Howell SG (2010) Flight feather molt of turkey vultures. Wilson J Ornithol 122: 354-360.

159. Proctor N, Lynch PJ (1993) Feathers. In: Manual of Ornithology: Avian Structure and Function. Yale University Press, MI. Chapter 4: 81-116.

160. Lucas AM, Stettenheim PR (1972) Avian anatomy: Integument. Agriculture Handbook. US Department of Agriculture, Washington, DC.

161. Dauwe T, Janssens E, Bervoets L, Blust R, Eens M (2004) Relationships between metal concentrations in great tit nestlings and their environment and food. Environ Pollut 131: 373-380.

162. Gochfeld M, Saliva J, Lesser F, Shukla T, Bertrand D, Burger J (1991) Effects of color on cadmium and lead levels in avian contour feathers. Arch Environ Contam Toxicol 20: 523-526.

163. Yu M, Yue Z, Wu P, Wu DY, Mayer JA (2004) The developmental biology of feather follicles. Int J Dev Biol 48: 181-191.

164. Sibley CG, Monroe BL (1990) Distribution and Taxonomy of Birds of the World. Yale University Press, New Haven, CT.

165. de la Hera I, Pérez-Tris J, Tellería JR (2009) Migratory behaviour affects the trade-off between feather growth rate and feather quality in a passerine bird. Biol J Linn Soc 97: 98-105.

166. Houston DC (1975) The moult of the white-backed and Rüppell's griffon vultures, Gyps Africans and G. rueppellii. Ibis 117: 474-488.

167. Han E, Yang W, Lee J, Park Y, Kim E,et al. (2005) Correlation of methamphetamine results and concentrations between head, axillary, and pubic hair. Forensic Sci Int 147: 21-24.

168. Cooper KM, McCracken RJ, Buurman M, Kennedy DG (2008) Residues of nitrofuran antibiotic parent compounds and metabolites in eyes of broiler chickens. Food Addit Contam 25: 548-556.

169. Malucelli A, Ellendorff F, Meyer HH (1994) Tissue distribution and residues of clenbuterol, salbutamol, and terbutaline in tissues of treated broiler chickens. J Anim Sci 72: 1555-1560.

170. Love DC, Halden RU, Davis MF, Nachman KE (2012) Feather meal: A previously unrecognized route for re-entry into the food supply of multiple pharmaceuticals and personal care products (PPCPs). Environ Sci Technol $46: 3795-3802$.

171. Nachman KE, Raber G, Francesconi KA (2012) Arsenic species in poultry meal feather. Sci Total Environ 417-418: 183-188.

172. Hagedorn HW, Zankl H, Grund C, Schulz R (1997) Excretion of the anabolic steroid boldenone by racing pigeons. Am J Vet Res 58: 224-227.

173. Lange IG, Daxenberger A, Hageleit M, Pfaffl MW, Meyer HHD (2003) Non-invasive screening for treatment of heifers with the anabolic steroid melengestrol acetate (MGA) by feces analysis. J Immunoassay Immunochem 24: 265-272.

174. Popot MA, Boyer S, Menaut L, Garcia P, Bonnaire Y, Lesage D (2008) Boldenone, testosterone and 1,4-androstadiene-3,17-dione determination in faeces from horses, untreated and after administration of androsta-1,4-diene-3,17-dione (boldione). Biomed Chromatogr 22: 662-670.

175. Van Puymbroeck M, Leyssens L, Vanderzande D, Gelan J, Raus J (1998) Metabolites in feces can be important markers for the abuse of anabolic steroids in cattle. Analyst $123: 2449-2452$.

176. Popot MA, Donval A, Bonnaire Y, Huau J (2006) Use of accelerating solvent extraction for detecting non-steroidal anti-inflammatory drugs in horse feces. J Anal Toxicol 30: 323-330.

177. Martinez JL (2009) Environmental pollution by antibiotics and by antibiotic resistance determinants. Environ Pollut 157: 2893-2902.

178. Smith SR (2009) A critical review of the bioavailability and impacts of heavy metals in municipal solid waste composts compared to sewage sludge. Environ Int 35: 142-156.

179. Hidalgo S, ZabalaJ, Zuberogoitia I, Azkona A, Castillo I (2005) Food of the Egyptian vulture (Neophron percnopterus) in Biscay. Buteo 14: 23-29.

180. Negro J, Grande J, Tella J, Garrido J, Hornero D, et al. (2002) Coprophagy: An unusual source of essential carotenoids. Nature 416: 807-808.

181. Cuthbert R, Green RE, Ranade S, Saravanan S, Pain DJ, et al. (2006) Rapid population declines of Egyptian vulture (Neophron percnopterus) and red-headed vulture (Sarcogyps calvus) in India. Animal Conserv 9: 349-354.

182. López-López P, García-Ripollés C, Urios V (2014) Food predictability determines space use of endangered vultures: implications for management of supplementary feeding. Ecol Appl, In Press.

183. Lumaret JP, Errouissi F (2002) Use of anthelmintics in herbivores and evaluation of risks for the nontarget fauna of pastures. Vet Res 33: 547-562.

184. Spratt DM (1997) Endoparasite control strategies: implications for biodiversity of native fauna. Int J Parasitol 27: 173-180.

185. Suarez VH (2002) Helminthic control on grazing ruminants and environmental risks in South America. Vet Res 33: 563-573.

186. Webb L, Beaumont DJ, Nager RG, McCracken D (2010) Field-scale dispersal of Aphodius dung beetles (Coleoptera: Scarabaeidae) in response to avermectin treatments on pastured cattle. Bull Entomol Res 100: $175-183$.

187. Brown PE, Christensen OF, Clough H, Diggle PJ, Hart CA (2004) Frequency and spatial distribution of environmental Campylobacter spp. Appl Environ Microbiol 70: 6501-6511.

188. Long RA, Donovan TM, Mackay P, Zielinski WJ, Buzas JS (2007) Comparing scat detection dogs, cameras, and hair snares for surveying carnivores. J Wildl Manage 71: 2018-2025.

189. Smith DA, Ralls, Hurt A, Adams B, Parker M, et al. (2003) Detection and accuracy rates of dogs trained to find scats of San Joaquin kit foxes (Vulpes macrotis mutica). Animal Conserv 6: 339-346.

190. Dahlgren DK, Elmore RD, Smith DA, Hurt A, Arnett EB (2012) Use of dogs in wildlife research and management. In: Silvy N.J. (Ed.), Wildlife Techniques Manual: Research, volume I. John Hopkins University Press, Baltimore, MD, Chapter 5: 140-153.

191. Bozarth CA, Alva-Campbell YR, Ralls K, Henry TR, Smith DA, et al. (2010) An efficient noninvasive method for discriminating among faeces of sympatric North American canids. Conservation Genet Resour 2: 173-175.

192. Weisbrod AV, Shea D, Moore MJ, Stegeman JS (2000) Organochlorine exposure and bioaccumulation in the endangered northwest Atlantic right whale (Eubalaena glacialis) population. Environ Toxicol Chem 19: 654-666.

193. Ayres KL, Booth RK, Hempelmann JA, Koski KL, Emmon CK, et al. (2012) Distinguishing the impacts of inadequate prey and vessel traffic 
Citation: Richards NL, Hall SW, Harrison NM, Gautam L, Scott KS, et al. (2014) Merging Wildlife and Environmental Monitoring Approaches with Forensic Principles: Application of Unconventional and Non-Invasive Sampling in Eco-Pharmacovigilance. J Forensic Res 5: 228. doi: $10.4172 / 2157-7145.1000228$

Page 15 of 16

on an endangered killer whale (Orcinus orca) population. PLoS ONE 7 e36842.

194. Rolland RM, Hamilton PK, Krauss SD, Davenport B, Gillett RM, et al. (2006) Faecal sampling using detection dogs to study reproduction and health in North Atlantic right whales (Eubalaena glacialis). J Cetacean Res Manage 8: 121-125.

195. Han SY, Son SW, Motokazu A, Sasaki H (1998) Heavy Metals and PCBs in Eurasian Otters (Lutra lutra) in South Korea. Proceedings of the 7th International Otter Colloquium: 103-109.

196. Kruuk H, Conroy JW (1996) Concentrations of some organochlorines in otters (Lutra lutra L.) in Scotland: Implications for populations. Environ Pollut 92: 165-71.

197. Mason CF, Macdonald SM (1994) PCBs and organochlorine pesticide residues in otters (Lutra lutra) and in otter spraints from SW England and their likely impact on populations. Sci Total Environ 144: 305-312.

198. van den Brink NW, Jansman HAH (2006) Applicability of spraints for monitoring organic contaminants in free-ranging otters (Lutra lutra). Environ Toxicol Chem 25: 2821-2826.

199. Cooper KM, Kennedy G (2005) Nitrofuran antibiotic metabolites detected as parts per million concentrations in retina of pigs - a new matrix for enhanced monitoring of nitrofuran abuse. Analyst 130: 466-468.

200. Ings RMJ (1984) The melanin binding of drugs and its implications. Drug Metab Rev 15: 1183-1212.

201. Donázar JA (1993) Los Buitres Ibéricos, Biología y Conservación. Ediciones de la Naturaleza, Madrid.

202. Guillot E, de Mazancourt P, Durigon M, Alvarez JC (2007) Morphine and 6-acetylmorphine concentrations in blood, brain, spinal cord, bone marrow and bone after lethal acute or chronic diacetylmorphine administration to mice. Forensic Sci Int 166: 139-144.

203. Drummer OH (2008) Drugs in Bone and Bone Marrow. In: Jenkins A.J., Capla Y.H. (Eds.), Drug Testing in Alternate Biological Specimens. Humana Press, Totowa, NJ, Chapter 8: 131-137.

204. McIntyre IM, King C, Boratto M, Drummer O (2000) Post-mortem drug analyses in bone and bone marrow. Ther Drug Monit 22: 79-83.

205. Raikos N, Tsoukali H, Njau SN (2001) Determination of opiates in postmortem bone and bone marrow. Forensic Sci Int 123: 140-141.

206. Tominaga M , Michiue T, Ishikawa T, Kawamoto O, Oritani S (2013) Postmortem analyses of drugs in pericardial fluid and bone marrow aspirate. J Anal Toxicol 37: 423-429.

207. Noguchi TT, Nakamura GR, Griesemer EC (1978) Drug analyses of skeletonizing remains. J Forensic Sci 23: 490-492.

208. Mehanna A (2003) NSAIDs: Chemistry and pharmacological actions. Am J Pharm Educ 67: 63.

209. Kojima T, Okamoto I, Miyazaki T, Chikasue F, Yashiki M (1986) Detection of methamphetamine and amphetamine in a skeletonized body buried for 5 years. Forensic Sci Int 31: 93-102.

210. Moffatt AC, Osselton MD, Widdop B (2004) Clarke's Analysis of Drugs and Poisons in Pharmaceuticals, Body Fluids and Post-mortem Material, (third edn). Pharmaceutical Press, London.

211. Menassé R, Hedwall PR, Kraetz, Pericin C, Riesterer L, et al. (1978) Pharmacological properties of diclofenac sodium and its metabolites. Scand J Rheumatol (Suppl) 7: 5-16.

212. Davies NM, Anderson KE (1997) Clinical pharmacokinetics of diclofenac: therapeutic insights and pitfalls. Clin Pharmacokinet 33: 184-213.

213. Risebrough RW (2006) Diclofenac: A new environmental poison in south Asia. J Bombay Nat Hist Soc 103: 239-250.

214. Margalida A (2008) Bearded vultures (Gypaetus barbatus) prefer fatty bones. Behav Ecol Sociobiol 63: 187-193.

215. Druid H, Holmgren P (1999) Fatal injections of heroin. Interpretation of toxicological findings in multiple specimens. Int J Legal Med 112: 62-66.

216. Goldberger BA, Cone EJ, Grant TM, Caplan YH (1994) Disposition of heroin and its metabolites in heroin-related deaths. J Anal Toxicol 18: $22-28$.
217. Bertone JJ, Lynn RC, Vatistas NJ, Kelch WJ, Sifferman RL (2002) Clinical Field Trial to Evaluate the Efficacy of Topically Applied Diclofenac Liposomal Cream for the Relief of Joint Lameness in Horses. 48th Proceedings of the American Association of Equine Practitioners: 190-193.

218. Medlicott NJ, Waldron NA, Foster PT (2004) Sustained release veterinary parenteral products. Adv Drug Delivery Rev 56: 1345-1365.

219. Van Hoof N, De Wasch K, Poelmans S, Noppe H, De Brabander H (2004) Multi-residue liquid chromatography / tandem mass spectrometry method for the detection of non-steroidal anti-inflammatory drugs in bovine muscle: optimisation of ion trap parameters. Rapid Commun Mass Spectrom 18: 2823-2829.

220. Lee CL, Miller Coyle H, Carita E, Ladd C, Yang NCS, et al. (2006) DNA analysis of digested tomato seeds in stomach contents. Am J Forensic Med Path 27: 121-125.

221. Pope L (2012) Identification of a second suspect via stomach contents at autopsy. J Assoc Crime Scene Reconstr 18: 13-15.

222. Milroy CM, Forrest AR (2000) Methadone deaths: A toxicological analysis. J Clin Pathol 53: 277-281.

223. Fajardo I, Velasco F (2011) Policia Científica Búsqueda e Identificación de Pruebas (Scientific Police Procedure: Search Techniques and Identification of Evidence). In: Fajardo I, Martín J. (Eds.), Manual de Protección Legal de la Biodiversidad para los Agentes de la Autoridad Ambiental en Andalucía, (second edn). Consejería de Medio Ambiente, Junta de Andalucía. Sevilla, Spain. Chapter 14: 318-363.

224. Sharma R, Garg RK, Gaur JR (2013) Contribution of various measures for estimation of post mortem interval from Calliphoridae: A review. Egyptian Journal of Forensic Sciences, In Press.

225. Catts EP (1992) Problems in estimating the postmortem interval in death investigations. J Agric Entomol 9: 245-255.

226. Fernández Verón I (2011) Datación de la Muerte del Cadáver y Entomología Cadavérica (Aging Carcasses and Forensic Entomology). In: Fajardo I. Martín J. (Eds.), Manual de Protección Legal de la Biodiversidad para los Agentes de la Autoridad Ambiental en Andalucía, (second edn). Consejería de Medio Ambiente, Junta de Andalucía. Sevilla, Spain. Chapter 16: 393-423.

227. Verma, K, Paul R (2013) Assessment of post mortem interval (PMI), from forensic entomotoxicological studies of larvae and flies. Entomol Ornithol Herpetol 2: 104-108.

228. Lumaret JP, Errouissi F, Floate K, Römbke J, Wardhaugh K (2012) A review on the toxicity and non-target effects of macrocyclic lactones in terrestrial and aquatic environments. Curr Pharm Biotechnol 13: 1004-1060.

229. Stromberg BE (1997) Environmental factors influencing transmission. Vet Parasitol 72: 247-264.

230. Dolan K, Rouen D, Kimber J (2004) An overview of the use of urine, hair sweat and saliva to detect drug use. Drug Alcohol Rev 23: 213-217.

231. Snyder NFR, Johnson EV, Clendenen DA (1987) Primary molt of California condors. Condor 89: 468-485.

232. Whittem T, Davis C, Beresford GD, Gourdie T (1998) Detection of morphine in mane hair of horses. Aust Vet J 76: 426-427.

233. Tracey S, Dunnett M, Langridge K, Redhead M, Wood A, et al. (2002) Effect of Breed and Environment on Mane and Tail Growth in a Mixed Group of Horses, 41st Congress of the British Equine Veterinary Association.

234. Sachs H, Raff I (1993) Comparison of quantitative results of drugs in human hair. Forensic Sci Int 63: 207-216.

235. Wennig R (2000) Potential problems with the interpretation of hair analysis results. Forensic Sci Int 107: 5-12.

236. http://www.save-vultures.org/[Accesed on April 16,2014]

237. http://www.rspb.org.uk/supporting/campaigns/impact/vulture/ nearlysaved.aspx [Accessed on April 16, 2014]

238. http://www.tiaft.org/node/86 [Accessed on April 16, 2014]

239. http://www.fws.gov/lab/featheratlas/index.php[Accessed on April 16, 2014] 
Citation: Richards NL, Hall SW, Harrison NM, Gautam L, Scott KS, et al. (2014) Merging Wildlife and Environmental Monitoring Approaches with Forensic Principles: Application of Unconventional and Non-Invasive Sampling in Eco-Pharmacovigilance. J Forensic Res 5: 228. doi: $10.4172 / 2157-7145.1000228$ 